NBER WORKING PAPER SERIES

\title{
NEGATIVE ALCHEMY? CORRUPTION, COMPOSITION OF CAPITAL FLOWS, AND CURRENCY CRISES
}

\author{
Shang-Jin Wei \\ $\mathrm{Yi} \mathrm{Wu}$ \\ Working Paper 8187 \\ http://www.nber.org/papers/w8187 \\ NATIONAL BUREAU OF ECONOMIC RESEARCH \\ 1050 Massachusetts Avenue \\ Cambridge, MA 02138 \\ March 2001
}

Wei is The New Century Chair in International Economics and Senior Fellow at Brookings Institution, a Research Fellow at Harvard University's Center for International Development, the National Bureau of Economic Research (U.S.) and the Center for Economic Policy Research (Europe). Wu is a Ph.D student at Georgetown University. This research project is supported in part by a grant from the OECD Development Center. We thank Marty Feldstein, Jeff Frankel, Helmut Reisen, Dani Rodrik, Andrei Shleifer for offering very helpful comments, Rafael di Tella, Ernesto Stein and Ugo Panizza for sharing their data, and Rachel Rubinfeld and Mike Prosser for superb research and editorial assistance. The views expressed herein are those of the authors and not necessarily those of the National Bureau of Economic Research.

(C) 2001 by Shang-Jin Wei and Yi Wu. All rights reserved. Short sections of text, not to exceed two paragraphs, may be quoted without explicit permission provided that full credit, including $\odot$ notice, is given to the source. 
Negative Alchemy? Corruption, Composition of Capital Flows, and Currency Crises

Shang-Jin Wei and Yi Wu

NBER Working Paper No. 8187

March 2001

JEL No. F2

\begin{abstract}
Crony capitalism and self-fulfilling expectations by international creditors are often suggested as two rival explanations for currency crisis. This paper examines a possible linkage between the two that has not been explored much in the literature: corruption may affect a country's composition of capital inflows in a way that makes it more likely to experience a currency crisis that is triggered/aided by a sudden reversal of international capital flows. We find robust evidence that poor public governance is associated with a higher loan-to-FDI ratio. Such a composition of capital flows has been identified as being associated with a higher incidence of a currency crisis. We also find some weaker evidence that poor public governance is associated with a country's inability to borrow internationally in its own currency. The latter is also associated with a higher incidence of a currency crisis. To sum up, even though crony capitalism does not forecast the timing of a crisis, it can nevertheless increase its likelihood. This paper illustrates a particular channel through which this can happen.
\end{abstract}

Shang-Jin Wei

Brookings Institution

1775 Massachusetts Ave. NW

Washington, DC 20036

Center for International Development

Harvard University

and NBER
$\mathrm{Yi} \mathrm{Wu}$

Department of Economics

Georgetown University

Washington, DC 20057 


\section{Motivation}

This paper studies the impact of corruption on a country's composition of capital inflows. The importance of this composition was recently highlighted by the currency crises in East Asia, Russia and Latin America. Several studies (starting with Frankel and Rose, 1996, and followed by Radlet and Sachs, 1998, and Rodrik and Velasco, 1999) have shown that the composition of international capital inflows is correlated with the incidence of currency crises. In particular, three types of composition measures have been highlighted in the literature as being particularly relevant for the discussion of currency crises: (a) the lower the share of foreign direct investment in total capital inflows, (b) the higher the short-term debt-to-reserves ratio, or (c) the higher the share of foreign currency denominated borrowing in a country's total borrowing, the more likely a currency crisis becomes.

In this paper, we will discuss all three dimensions of the composition of capital flows, but with a greater emphasis on the FDI share in total capital inflows, as we have a larger set of observations and more reliable measure on this. We will explain this later. One possible reason for why a low FDI share in total capital flow is associated with a higher probability of crises is that bank lending or other portfolio investment may be more sentiment-driven than direct investment. Hence, a small (unfavorable) change in the recipient countries' fundamentals may cause a large swing in the portfolio capital flows (e.g., from massive inflows to massive outflows). This can strain the recipient country's currency or financial system sufficiently to cause or exacerbate its collapse (Radelet and Sachs, 1998; Rodrik and Velasco, 1999; Reisen, 1999).

There are at least two views on the causes of the crises. On the one hand, it is increasingly common to hear the assertion that so-called "crony capitalism" may be partly responsible for the onset and/or the depth of the crises. Direct statistical evidence is so far sparse on this hypothesis, with the notable exception of Johnson, etc. $(2000)^{1}$. On the other hand, many researchers argue that (fragile) self-fulfilling expectations by

\footnotetext{
${ }^{1}$ For surveys of the literature on corruption and economic development, see Bardhan (1997), Kaufmann (1997), and Wei (1999). More recent papers on corruption include Wei (2000c) and Bai and Wei (2000). None of the surveys covers any empirical study that links crony capitalism with currency crisis.
} 
international creditors are the real reason for the currency crisis. Crony capitalism and self-fulfilling expectations are typically presented as rival explanations.

There may be a linkage between the two hypotheses. The extent of corruption in a country may affect that country's composition of capital inflows in a way that makes it more vulnerable to international creditors' shifts in expectations.

In a narrow sense of the word, "corruption" refers to the extent to which firms (or private citizens) need to pay bribes to government officials in their interactions (for permits, licenses, loans, and so forth $)^{2}$. However, we prefer to think of corruption more broadly as a short-hand for "poor public governance," which can include not only bureaucratic corruption, but also deviations from rule of law or excessive and arbitrary government regulations. All the existing empirical indicators of the different dimensions of public governance are so highly correlated, that we do not think that we can separately identify their effects at this stage.

There are a small number of previous papers that have looked at the effect of corruption on foreign direct investment. Mixing corruption with twelve other variables to form a composite indicator, Wheeler and Mody (1992) failed to find a significant relation between corruption and foreign investment. However, the insignificant result may be due to a high noise-to-signal ratio in the composite indicator. Using U.S. outward investment to individual countries, Hines (1995) did find that foreign investment is negatively related to host country corruption, which he interpreted as evidence of the effect of the U.S. Foreign Corrupt Practices Act. Using a matrix of bilateral international direct investment from twelve source countries to forty-five host countries, Wei (2000a) found that the behavior of the FDI flows from the U.S. and of those from other source countries, with respect to host country corruption, are not statistically different. But more importantly, corruption not only has a negative and statistically significant coefficient, it has an economically large effect on inward foreign direct investment. For example, in a benchmark estimation, an increase in corruption from the level of Singapore to that of

\footnotetext{
${ }^{2}$ We use the term "crony capitalism" interchangeably with "corruption." Strictly speaking, "crony capitalism" refers to an economic environment in which relatives and friends of government officials are placed in positions of power and government decisions on allocation of resources are distorted to favor friends and relatives. In reality, "crony capitalism" almost always implies a widespread corruption as private firms and citizens in such an environment find it necessary to pay bribes to government officials in order to get anything done.
} 
Mexico would have the same negative effect on inward foreign investment as raising the marginal corporate tax by fifty percentage points. Using firm-level data, Smarzynska and Wei (2000) found that host country corruption induces foreign investors to favor joint ventures (over wholly owned firms).

None of the above papers has a measure of government policies towards FDI. Such data are not readily available. The current paper employs two new indexes of government policies towards FDI that are compiled from investment guides for individual countries produced by PricewaterhouseCoopers (2000). While FDI is an important element of this study, the main focus is to examine the effect of corruption on the composition of capital inflows (FDI versus borrowing from foreign banks, in particular). We are not aware of any studies that have examined this question except for Wei(2000c). This paper extends the previous paper in several ways. While Wei(2000c) focuses on the connection between the ratio of bank loan to FDI and corruption, and bases the analysis on bilateral data, this paper also checks the relative share of portfolio flows versus FDI and also uses more aggregate data from the balance-of-payments reported by the countries to the IMF. In addition, we report results on a possible relationship between corruption and the maturity structure of foreign borrowing, and between corruption and a country's ability to borrow internationally in its own currency.

Before proceeding to a more formal analysis, it may be useful to have a quick glance of the data. The argument that capital flow composition matters requires that different capital flows have a different level of volatility. For every member country of the IMF for which relevant data is available for 1980-1996, we compute the standard deviations of three ratios (portfolio capital inflow/GDP, borrowing-from-banks/GDP, and inward FDI/GDP) ${ }^{3}$. The results are summarized in Table 1a and visually presented in

\footnotetext{
${ }^{3}$ Hausmann and Fernandez-Arias (2000) argue that the classification of capital inflows into FDI and other forms may not be accurate, and that it is possible for a reversal of an inflow of FDI to take the form of an outflow of bank loans or portfolio flows. As a result, calculations of relative volatility of the different forms of capital flows are not meaningful. We hold a different view. The misclassification can come from two sources: random measurement errors and intentional mis-reporting by international investors. In the first instance, if capital flows are misclassified at the margin due to random errors, the labels on FDI and other forms of capital flows are still useful. In the second instance, foreign investors may intentionally misreport types of capital flows. Since there is a cost associated with mis-reporting, there is a limit on the magnitude of the error of this type as well. In the empirical work to be presented later in the paper, the bilateral FDI data are based on FDI source country governments' survey of their firms. The bilateral bank lending data are based on international lending banks' reporting to their governments (which then forward
} 
Figure 1. For all countries in the sample (103 countries in total), the volatility of FDI/GDP ratio is substantially smaller than the loan/GDP ratio and somewhat smaller than the ratio of portfolio flows /GDP. For the non-OECD countries as a group, the FDI/GDP ratio is also much less volatile than the loan/GDP ratio, although its median is higher than the portfolio flow/GDP ratio. The lower part of the same table presents the volatility of the three ratios for a number of individual countries that featured prominently in the recent currency crises. Each country shows a loan/GDP ratio that is at least twice and as much as fifteen times as volatile as the FDI/GDP ratio. For each of these countries, the portfolio capital/GDP ratio is also more volatile than the FDI/GDP ratio. If the sample period is extended to include 1997-98, the differences in volatility would be even more pronounced (not reported). Alternatively, we may look at the coefficient of variation (standard deviation divided by the mean) of these three ratios. These results are presented in Table 1b. Again, for the group of emerging market economies, FDI/GDP is less volatile than the loan/FDI ratio according to this measure. On the other hand, FDI/GDP is less volatile than the portfolio/GDP ratio according to median in the group, but not according to the mean of the group. Therefore, the data is consistent with the hypothesis that FDI is less sentiment-driven and hence more stable as a source of foreign capital ${ }^{4}$.

Corruption is bad for both international direct investors and creditors. Corrupt borrowing countries are more likely to default on bank loans, or to nationalize (or otherwise diminish the value of) the assets of foreign direct investors. When this happens, there is a limit on how much international arbitration or court proceedings can help to recover the assets, as there is a limit on how much collateral the foreign creditors or direct investors can seize as compensation ${ }^{5}$.

One may argue that domestic investors have an informational advantage over international investors. Among international investors, international direct investors may have an informational advantage over international portfolio investors (and presumably banks). International direct investors could obtain more information about the local

${ }^{4}$ The pattern reported here is the opposite to Dooley, Claessens and Warner (1995). 
market by having managers from the headquarters stationing in the country that they invest in. As a consequence, the existence of cross-border informational asymmetry may lead to a bias in favor of international direct investment. This is the logic underlying Razin, Sadka and Yuen's theory of (1998) of “pecking order of international capital flows." However, the existence of corruption could temper this effect. The need for international investors to pay bribery and deal with extortion by corrupt bureaucrats tends to increase with the frequency and the extent of their interactions with local bureaucrats. Given that international direct investors are more likely to have repeated interactions with local officials (for permits, taxes, health inspections, and so forth) than international banks or portfolio investors, local corruption would be more detrimental to FDI than other forms of capital flows. Along the same line, direct investment involves greater sunk cost than bank loans or portfolio investment. Once an investment is made, when corrupt local officials start to demand bribery (in exchange for not setting up obstacles), direct investors would be in a weaker bargaining position than international banks or portfolio investors. This ex post disadvantage of FDI would make international direct investors more cautious ex ante in a corrupt host country than international portfolio investors ${ }^{6}$.

There is a second reason why international direct investment is deterred more by local corruption than international bank credit or portfolio investment. The current international financial architecture is such that international creditors are more likely to be bailed out than international direct investors. For example, during the Mexican (and subsequent Tequila) crisis and the more recent Asian currency crisis, the IMF, the World Bank, and the G7 countries mobilized a large amount of funds for these countries to prevent or minimize the potentially massive defaults on bank loans. So an international bailout of the bank loans in an event of a massive crisis has by now been firmly implanted in market expectations. [In addition, many developing country governments implicitly or explicitly guarantee the loans borrowed by the private sector in the

\footnotetext{
${ }^{5}$ In the old days, major international creditors and direct investors might rely on their navies to invade a defauting countries to seize more collateral. Such is no longer a (ready) option today.

6 Tornell (1990) presented a model in which a combination of sunk cost in real investment and uncertainty leads to under-investment in real projects even when the inflow of financial capital is abundant.
} 
country $^{7}$ ]. In comparison, there have been no comparable examples of international assistance packages for the recovery of nationalized or extorted assets of foreign direct investors except for an insignificant amount of insurance that is often expensive to acquire. This difference further tilts the composition of capital flows and makes banks more willing than direct investors to do business with corrupt countries.

Both reasons suggest the possibility that corruption may affect the composition of capital inflows in such a way that the country is more likely to experience a currency crisis. Of course, the composition of capital flows impacts economic development in ways that go beyond its effect on the propensity for a currency crisis. Indeed, many would argue that attracting FDI as opposed to international bank loans or portfolio investment is a more useful way to transfer technology and managerial know-how.

As some concrete examples, Table 2 shows the total amount of inward foreign direct investment, foreign bank loans, portfolio capital inflows, and their ratios for New Zealand, Singapore, Uruguay and Thailand. Figure 2 summarizes the comparison by pie charts. On the one hand, New Zealand and Singapore (are perceived to) have relatively low corruption (the exact source is explained in the next section) and relatively low loan/FDI and portfolio investment/FDI ratios. On the other hand, Uruguay and Thailand (are perceived to) have relatively high corruption and relatively high loan/FDI and portfolio investment/FDI ratios. So these examples are consistent with the notion that local corruption is correlated with patterns of capital inflows. Of course, these four countries are just examples. As such, there are two questions that need to be addressed more formally. First, does the association between corruption and composition of capital flows generalize beyond these four countries? Second, once we control for a number of other characteristics that affect the composition of capital inflows, would we still find the positive association between corruption and the loan/FDI ratio?

Aside from measuring composition of capital inflows in terms of the relative share of the FDI versus non-FDI, two other compositions of capital flows have been suggested to be relevant in discussing currency crises. The first is the term structure of foreign borrowing. It has been suggested that the higher the share of short term

\footnotetext{
${ }^{7}$ McKinnon and Pill (1996 and 1999) argue that the government guarantee generates "moral hazard" which in turn leads the developing countries to "overborrow" from the international credit market.
} 
borrowing in a country's total borrowing, the more likely the country may run into a future crisis (Rodrik and Velasco, 1999). The second is the currency denomination of the foreign borrowing. It has been hypothesized that the greater the share of international borrowing that is denominated in a hard currency (most often the U.S. dollar), the more likely a country may run into a future crisis. In this connection, the inability for a country to borrow internationally in its own currency (which would have reduced the probability of a crisis) has been termed "original sin" (Hausmann and Fernandez-Arias, 2000). The limitation of the data places a more severe constraint on measuring well these two composition of international borrowing. Nonetheless, in the later part of the paper, we will also report some preliminary findings regarding possible linkages between corruption and these measures of the composition of foreign borrowing.

We organize the rest of the paper in the following way. Section 2 describes the data. Section 3 presents the methodology and the statistical results of the analyses. And Section 4 concludes.

\section{Data}

The key components of international capital flows in the empirical investigation are bilateral direct investment and bilateral bank loans. To our knowledge, other forms of capital flows are not available on a bilateral basis for a broad set of capital-exporting countries examined in this paper.

The bilateral foreign direct investment (FDI) data is an average over three years (1994-96) of the stock of foreign direct investment from 18 source countries to 59 host countries. Table 3 presents a list of all source and host countries in our sample. The data comes from the OECD's International Direct Investment 1998. To reduce year-toyear fluctuation in the data due to measurement error, the simple average over 1994-96 (year-end stocks) is used.

The bilateral bank lending data is an average over three years of the outstanding loans from 13 lending countries to 83 borrowing countries. After excluding missing observations, there are altogether 793 country pairs. The data comes from the Bank for International Settlement's Consolidated International Claims of BIS Reporting Banks on 
Individual Countries, and is given in millions of dollars. To reduce measurement errors in a given year, we use the simple average over three years (1994-96, year-end outstanding amounts).

Term structure of bank lending. The BIS data identifies loans with "maturity up to and including one year," "maturity over one year up to two years," "maturity over two years," and "unallocated maturity." This data is dis-aggregated by borrowing countries, but not by the lender-borrower pairs. Consequently, we construct a measure of the term structure of borrowing at the borrowing country level as the ratio of all outstanding bank loans with maturity up to and including one year to total loans. We also construct an alternative of the importance of short-term borrowing as the ratio of the short-term borrowing (loans up to and including one year) to the sum of total loans and inward FDI.

Corruption. By its very nature (of secrecy and illegality), the level of corruption is difficult to measure. There are three types of measures of corruption available, and all are perception-based subjective indexes. The first is a rating given by consulting firms' in-house consultants or "experts." Representative indexes are produced by the Business International (BI, now part of the Economist's Economic Intelligence Unit), and by Political Risk Services (which call its product "International Country Risk Group" or ICRG rating). The second type is based on survey of business executives (or other people in the country in question). The rating for a country is typically the average of the respondent's ratings. Examples of this include indexes in the Global Competitiveness Report (GCR) and World Development Report (WDR), which will be explained in more detail shortly. The third type is based on an average of existing indexes. The best known example is the index produced by Transparency International (TI), a Germany-based nongovernmental organization devoted to fighting corruption. A drawback of this type of index is that mixing indexes with different country coverage and methodologies could potentially introduce more noise to the measure.

Overall, corruption ratings based on surveys of firms are preferable to those based on the intuition of in-house experts. First, the executives who respond to the GCR or WDR surveys presumably have more direct experience with the corruption problem than the consultants who each typically have to rate many countries. Second, to the extent each individual respondent has idiosyncratic errors in his/her judgement, the averaging process 
in the WDR or WCR indexes can minimize the influence of such errors. In this paper, we use the indexes from the GCR and WDR surveys as our basic measure of corruption.

The GCR Index is derived from the Global Competitiveness Report 1997, produced jointly by the Geneva-based World Economic Forum and Harvard Institute for International Development. The survey for the report was conducted in late 1996 on 2827 firms in 58 countries. The GCR Survey asked respondents (in Question 8.03) to rate the level of corruption in their country on a one-to-seven scale, based on the extent of "irregular, additional payments connected with imports and exports permits, business licenses, exchange controls, tax assessments, police protection or loan applications." The GCR Corruption Index is based on the country average of the individual ratings.

The WDR Index is derived from a World Bank survey in 1996, of 3866 firms in 73 countries, in preparation for its World Development Report 1997. Question 14 of that survey asks: "Is it common for firms in my line of business to have to pay some irregular, 'additional' payments to get things done?" The respondents were asked to rate the level of corruption on a one-to-six scale. The WDR corruption index is based on the country average of the individual answers. For both corruption indexes, the original sources are such that a higher number implies lower corruption. To avoid awkwardness in interpretation, they are re-scaled in this paper so that a high number now implies high corruption.

Since each index covers only a (different) subset of countries for which we have data on FDI or other forms of capital flows, it may be desirable to form a composite corruption index that combines the two indexes. The two indexes are derived from surveys with similar methodologies and similar questions. The correlation between the two is 0.83 . We follow a simple three-step procedure to construct the composite index: (a) Use GCR as the benchmark; (b) Compute the average of the individual ratios of GCR to WDR for all countries that are available in both GCR and the WDR; and (3) For those countries that are covered by WDR but not GCR (which is relatively rare), we convert the WDR rating into the GCR scale by using the average ratio in (b).

Government policies towards foreign direct investment. We rely on detailed descriptions compiled by the PricewaterhouseCoopers $(\mathrm{PwC})$ in a series of country reports titled, "Doing Business and investing in China" or in whichever country that may 
be the subject of the report. The "Doing Business and investing in ..." series is written for multinational firms intending to do business in a particular country. They are collected in one CD-Rom titled "Doing Business and Investing Worldwide" (PwC, 2000). For each potential host country, the relevant PwC country report covers a variety of legal and regulatory issues of interest to foreign investors, including "Restrictions on foreign investment and investors" (typically Chapter 5), "Investment incentives" (typically Chapter 4), and "Taxation of foreign corporations" (typically Chapter 16).

With a desire to convert textual information into numerical codes, we read through the relevant chapters for all countries that the PwC covers. For "restrictions on FDI," we create a variable taking a value from zero to four, based on the presence or absence of restrictions in the following four areas:

(a) Existence of foreign exchange control. (This may interfere with foreign firms' ability to import intermediate inputs or repatriate profits abroad).

(b) Exclusion of foreign firms from certain strategic sectors (particularly, national defense and mass media).

(c) Exclusion of foreign firms from additional sectors that would otherwise be considered harmless in most developed countries.

(d) Restrictions on foreign ownership (e.g., they may not have 100\% ownership).

Each of the four dimensions can be represented by a dummy that takes the value one (in the presence of the specific restriction) or zero (in the absence of the restriction). We create an overall "FDI Restriction" variable that is equal to the sum of these four dummies. "FDI restriction" is zero if there is no restriction in any of the four categories, and four if there is restriction in each category.

Similarly, we create an "FDI incentives" index based on information in the following areas. 
(a) Existence of special incentives to invest in certain industries or certain geographic areas.

(b) Tax concessions specific to foreign firms (including tax holidays and tax rebates, but excluding tax concessions specifically designed for export promotion, which is in a separate category).

(c) Cash grants, subsidized loans, reduced rent for land use, or other nontax concessions, specific to foreign firms.

(d) Special promotion for exports (including existence of export processing zones, special economic zones, etc).

An overall "FDI incentives" variable is created as the sum of the above four dummies. So it can take a value of zero if there is no incentive in any of the four categories, and four if there are incentives in all of them.

Our coding of the incentives/restrictions measures are still coarse and may not capture the true variations of the government policies. Nonetheless, it is important to have a way to control for these types of government policies in a statistical analysis of international capital flows. Our contribution is to create a first-of-this-kind index. We let the data speak to the usefulness of such an index.

Table 3 lists all the countries in our sample. Tables $4 \mathrm{a}$ and $4 \mathrm{~b}$ presents the summary statistics for some key variables and the coefficients of the pair-wise correlation among the three measures of corruption and GDP per capita.

\section{Statistical Analyses}

To study the effect of corruption on the composition of capital inflows is equivalent to asking whether corruption may have a differential impact on different forms of capital flows. In this section, we proceed by sequentially examining foreign direct investment, international bank lending, and ratio between the two.

\section{$\underline{3.1 \text { Corruption and foreign direct investment }}$}


We first examine the effect of local corruption on the volume of inward foreign direct investment. Our specification can be motivated by a simple optimization problem solved by a multinational firm. Let $\mathrm{K}(\mathrm{j})$ be the stock of investment the multinational firm intends to allocate to host country $\mathrm{j}$. Let $\mathrm{t}(\mathrm{j})$ be the rate of corporate income tax in host country $j, b(j)$ be the rate of bribery the firm has to pay per unit of output, and $r$ be the rental rate of capital. Let $f[K(j)]$ be the output of the firm in host country $j$. There are $N$ possible host countries that the firm can invest in. The firm chooses the level of $\mathrm{K}(\mathrm{j})$ for $j=1,2, \ldots, N$, in order to maximize its total after-tax and after-bribery profit:

$\pi=\sum_{j=1}^{N}\{[1-t(j)-b(j)] f[K(j)]-r K(j)\}$

Note that as a simple way to indicate that tax and corruption are distortionary, we let [1-t(j)-b(j)] pre-multiply output rather than profit. The optimal stock of FDI in country $j$, $\mathrm{K}(\mathrm{j})$, would of course be related to both the rate of tax and that of corruption in the host country: $\mathrm{K}=\mathrm{K}[\mathrm{t}(\mathrm{j}), \mathrm{b}(\mathrm{j})]$, where $\partial \mathrm{K} / \partial \mathrm{t}<0$ and $\partial \mathrm{K} / \partial \mathrm{b}<0{ }^{8}$.

Let $\operatorname{FDI}(\mathrm{k}, \mathrm{j})$ be the bilateral stock of foreign direct investment from source country $\mathrm{k}$ to host country $\mathrm{j}$. In our empirical work, we start with the following benchmark specification:

$$
\log [\operatorname{FDI}(k, j)]=\Sigma_{i} \alpha(i) D(i)+\beta_{1} \operatorname{tax}(j)+\beta_{2} \operatorname{corruption}(j)+X(j) \delta+Z(k, j) \gamma+e(k, j)
$$

where $\mathrm{D}(\mathrm{i})$ is a source country dummy that takes the value of one if the source country is $\mathrm{i}$ (i.e., if $\mathrm{k}=\mathrm{i}$ ), and zero otherwise; $\mathrm{X}(\mathrm{j})$ is a vector of characteristics of host country $\mathrm{j}$ other than its tax and corruption levels; $Z(k, j)$ is a vector of characteristics specific to the source-host country pairs; $\mathrm{e}(\mathrm{k}, \mathrm{j})$ is an iid error that follows a normal distribution; and $\alpha(\mathrm{i}), \beta_{1}, \beta_{2}, \delta$, and $\gamma$ are parameters to be estimated.

\footnotetext{
${ }^{8}$ More sophisticated generalization includes endogenizing the level of corruption (and tax) such as those in Shleifer and Vishny (1993) or Kaufmann and Wei (1999). These generalizations are outside the scope of the current paper.
} 
This is a quasi-fixed-effects regression in that source country dummies are included. They are meant to capture all characteristics of the source countries that may affect the size of their outward FDI, including their size and level of development. In addition, possible differences in the source countries' definition of FDI are controlled for by these fixed effects under the assumption that the FDI values for a particular country pair under these definitions are proportional to each other except for an additive error that is not correlated with other regressors in the regression. We do not impose host country fixed effects, as doing so would eliminate the possibility of estimating all the interesting parameters including the effect of corruption.

Using the combined GRC/WDR rating as the measure of corruption, the regression is run and reported in the first column of Table 5. Most variables have the expected signs and are statistically significant. A rise in host country tax rate is associated with less inward FDI. Government incentives and the restrictions on FDI have a positive and a negative coefficient, respectively, consistent with our intuition. Most importantly, corruption has a negative and statistically significant effect on FDI. Note that in the regressions, we have standardized the corruption measure (by subtracting the mean and dividing it by the sample standard deviation) so that the point estimate can be interpreted as the response of the left-hand-side variable with respect to a one-standarddeviation increase in corruption. Therefore, using the GCR/WDR measure of corruption (the first two columns of Table 5), a one-standard-deviation increase in corruption is associated with a $40 \%$ decline in FDI. In other words, the negative effect of corruption is not just statistically significant, it is quantitatively large. This finding is qualitatively in line with Wei (2000a), which employed a different econometric specification.

We perform several robustness checks. First, we add host country random effects to the specification. The regression result is reported in the second column of Table 5. The point estimate on corruption declines slightly, but remains negative and significant. We also adopt an alternative measure of corruption from the Transparency International and repeated the regressions (Columns 3-4 in Table 5). The qualitative results are unchanged. The estimated elasticity of FDI with respect to corruption is somewhat larger: a one-standard-deviation in corruption in the host country is associated with a $50 \%$ drop in inward FDI. 


\section{$\underline{3.2 \text { Corruption and Composition of Capital Inflows }}$}

We now move to the central empirical question in the paper: does corruption affect the composition of capital inflows? This is equivalent to asking whether corruption affects FDI and international bank loans differently. We start by examining the relationship between corruption and bilateral bank loans, in a manner analogous to our previous studies of bilateral FDI (except that government policies towards FDI and tax rate on foreign-invested firms are omitted $)^{9}$.

Table 6 reports four regressions, with different specifications (just source country fixed effects, or with additional host country random effects), or with difference sources of corruption measures (GCR/WDR and Transparency International Index). The results are basically consistent (and somewhat surprising). When corruption is measured by the GCR/WDR index, it has a positive and statistically significant coefficient. In other words, in contrast with the previous results on FDI, corruption in borrowing countries seems to be associated with a higher level of borrowing from international banks. In Appendix 4, we also restrict the sample to a single lending country (such as France, Japan, and the United States). Generally speaking, the coefficient on corruption in the loan regression continues to be positive (though not always significant).

The earlier part of the paper suggests two stories in which international direct investors are more discouraged by local corruption than international banks. The first is that greater sunk costs or greater ex post vulnerability of the direct investment would make direct investors more cautious ex ante than international banks in doing business in a corrupt host country. The second is the greater probability of an implicit or explicit bailout provided by the current international financial system to international loans than international direct investment. These stories explain only a compositional shift away from FDI towards bank loans in corrupt recipient countries. Are they also consistent with an absolute increase in the borrowing from international banks by corrupt countries? One possibility is that FDI and international bank loans are imperfect substitutes. In a corrupt

\footnotetext{
9 We have not found a consistent data source on government policies towards international bank borrowing across countries, nor are we able to construct such a series from the PwC country reports.
} 
recipient country, precisely because of the lost FDI due to corruption, there are relatively more activities that need to be financed by borrowing from international banks ${ }^{10}$.

In Columns 3 and 4 of Table 6 , an alternative measure of corruption by the TI index is used. This time, corruption still has a positive coefficient, although the estimate is not statistically different from zero when host country random effects are added.

Putting the results on FDI and bank loans together, it would seem natural to expect that corruption would raise the ratio of bank loans to FDI. To verify that this is indeed the case, we also check directly the connection between the ratio of bank loans to FDI and host country corruption. We perform a fixed-effects regression of the following sort:

$$
\log \left(\operatorname{Loan}_{\mathrm{kj}} / \mathrm{FDI}_{\mathrm{kj}}\right)=\quad \begin{aligned}
& \text { source country } \\
& \text { fixed effects }
\end{aligned}+\beta \text { corruption }_{\mathrm{j}}+\mathrm{X}_{\mathrm{kj}} \Gamma+\mathrm{e}_{\mathrm{kj}}
$$

The regression results are reported in the first four columns in Table 7. As expected, the coefficient on corruption is positive and statistically significant at the 5 percent level. Using the point estimate in the first regression, we see that a one-standarddeviation increase in corruption is associated with roughly a $66 \%$ increase in the loan-toFDI ratio (e.g., roughly from $100 \%$ to $166 \%$ ).

Based on the first regression in Table 7, Figure 3 presents a partial scatter plot of loan-to-FDI ratio against corruption, controlling for several characteristics of the host countries as described in the regression. A visual inspection of the plot suggests that positive association between corruption and capital composition is unlikely to go away if we omit any one or two observations. Hence, the evidence suggests that a corrupt country tends to have a composition of capital inflows that is relatively light in FDI and relatively heavy in bank loans.

Also note that because FDI is more relationship-intensive (as proxied by physical and linguistic distances) than bank loans, the coefficients on geographic distance and the linguistic tie dummy are positive and negative, respectively.

\footnotetext{
${ }^{10}$ Following a suggestion from Martin Feldstein, we have added other determinants of FDI, specifically, tax, government restrictions on inward FDI, and government incentives for FDI into the loan regression. Our objective is to see whether other factors that discourage (or encourage) FDI would show up as encouraging (or discouraging) international bank loans. Unfortunately, these variables are statistically not different from zero. An example of this is reported as Column 2 of Appendix 4.
} 
One might be concerned with possible endogeneity of the corruption measure. For example, survey respondents may perceive a country to be corrupt in part because they observe very little FDI going there. In this case, the negative association between the FDI-to-loan ratio and corruption can be due to a reverse causality.

In this subsection, we perform instrumental variable (IV) regressions on our key regressions. Mauro (1995) argued that ethnolinguistic fragmentation is a good IV for corruption. His ethnolinguistic indicator measures the probability that two persons from a country are from two distinct ethnic groups. The greater the indicator, the more fragmented the country. In addition, La Porta, etc. (1998) argued that legal origin or colonial history has an important impact on the quality of government bureaucracy. These variables are used as instruments for the corruption measure. A first-stage regression suggests that ethnically more fragmented countries are more corrupt. In addition, countries with a French legal origin (which includes colonies of Spain and Portugal) are more corrupt than former British colonies.

The IV regressions are reported in the last two columns of Table 7. A test of over-identifying restrictions does not reject the null hypothesis that the instruments are uncorrelated with the error term. The results from these two IV regressions are still consistent with the notion that corruption deters FDI more than bank loans. Therefore, countries that are more corrupt tend to have a capital inflow structure that relies relatively more on bank borrowing than FDI.

Our sample is potentially censored. A source country may choose not to invest at all in a particular host country precisely because of the corruption level and other characteristics of that country. In that case, either FDI or bank lending or both may be zero. The regression procedure used so far would drop these observations. However, our left-hand-side variable, the ratio of bank loans to FDI, does not lend itself naturally to a Tobit specification. For this reason, the following transformation of the ratio is constructed as the left-hand-side variable: $\log ($ bank lending +0.1$)-\log (F D I+0.1)$. The results are presented in Table 8 . With this new variable, there is a small increase in the number of observations (from 225 to 231). The most important message from Table 8 is that the earlier conclusion remains to be true: corruption tilts the composition of capital inflows away from FDI and towards international bank loans. 


\section{$\underline{3.3 \text { Portfolio and Direct Investments from the U.S. }}$}

While bilateral data on portfolio investment other than bank credits are not available for the whole set of capital-exporting countries examined in the previous subsections, we can obtain data on portfolio investment originating from the US (to a set of developing countries). In this subsection, the data on US outward capital flows is used to examine whether the portfolio-to-direct investment ratio in a capital-receiving country is affected by its corruption level. We have to caution at the onset that the number of observations is small (between 35 to 39 depending on the regression specification). So the power of the statistical tests is likely to be low.

Six fixed-effects regressions are performed and reported in Table 9. In the first three columns, we use the GCR/WDR indicator of corruption. We see again that, at least for this sub-sample, the portfolio-investment-to-FDI ratio is also positively related to the capital-importing country's corruption level. The more corrupt a country, the less FDI it receives (relative to portfolio capital). However, when we use the Transparency International (TI) corruption index (in the last three columns), the coefficients on corruption are no longer statistically significant although they are always positive. The insignificance can be consistent with a genuinely zero coefficient or can result from a low power of the test due to the small sample size.

\subsection{Evidence from the Balance-of-Payments Data}

If we are willing to forgo bilateral data and employ data from the balance-ofpayments statistics, we may be able to include more capital-importing countries in our analysis $^{11}$. In particular, we continue to use the portfolio inflow-to-FDI ratio, or the loanto-FDI ratio as the dependent variable. To minimize the effect of year-to-year fluctuation, we again average the ratios over a three-year period (1994-96).

The results are reported in Table 10a. In the first column where the dependent variable is the ratio of portfolio and FDI, we can see that corruption (as measured by a hybrid of GCR and WDR) is positive and statistically significant: more corrupt countries

\footnotetext{
${ }^{11}$ Note, however, that the number of observations with the BOP data may not be greater than that with the bilateral loan/FDI data.
} 
on average attract more portfolio inflows than FDI. In the next column, we examine the loan/FDI ratio as the dependent variable. The corruption variable is not significant. However, we observe that many other regressors are not significant either. If we drop two of the insignificant regressors (FDI incentives and restrictions), then the coefficient on corruption becomes positive and significant. If we further drop two additional insignificant variables (tax rate and exchange rate volatility), corruption remains positive and significant. So even with the BOP data, there is evidence that corrupt countries would have greater difficulties in attracting FDI relative to bank loans. In the last two columns of Table 10a, we use a different measure of corruption (TI index). The results remain the same: corruption discourages FDI more than bank loans or portfolio inflows.

We repeat the exercise with the left-hand-side variables over a different time period (1997-98), which is the period that Hausmann and Fernandez-Arias (2000) examined. The regression results are reported in Table 10b. Contrary to their inference, we find the exact same pattern as in our previous tables, namely, corrupt countries on average have relatively more difficulties in attracting FDI than the other forms of capital inflows.

\subsection{Maturity Structure of the Foreign Borrowing}

A different dimension of the capital flow composition, namely, the relative share of the short-term borrowing, has been stressed in the literature as also related to the likelihood of a currency crisis (see Rodrik and Velasco, 1999).

We look into the possible connection between this measure of composition of capital inflows and corruption. The results are reported in Table 11. It turns out that there is no robust evidence for a systematic relationship between the two. Thus, contrary to the share of FDI in total capital flows, higher corruption, per se, may not be associated with a greater reliance on short-term borrowing.

\subsection{Currency Structure of Foreign Borrowing}

Countries that experience a balance of payments crisis are often blamed to have either too much short-term borrowing or too much borrowing in a hard currency. Of course, both the tendency to borrow short-term and the tendency to borrow in a hard 
currency are linked to a country's inability to borrow internationally in its own currency, something that Hausmann and Fernandez-Arias called "original sin."

Using the ratio of international bonds issued in a country's currency to all international bonds issued by that country as a measure of a country's ability to borrow in its own currency, we can examine possible connections between a country's extent of corruption and this ability to borrow in its own currency. The results are reported in Table 12. When we use the GCR/WDR measure of corruption, there is a negative and statistically significant association between corruption and the ability to borrow in its own currency. This negative association remains when we add income level as a control. On the other hand, when we use an alternative measure of corruption (the TI index) and when income level is controlled for, the coefficient on corruption is no longer significant (although still negative). We have also tried a Tobit specification where zero percent issuance of international debt in a country's own currency is assumed to be censored from below. The coefficient on corruption is negative if there is no per capita income in the regression but insignificantly different from zero if there is per capita income. Overall, there is some (weak) support for the notion that higher corruption is associated with a lower ability to borrow internationally in one's own currency. This may be considered a piece of corroborative evidence that corruption may have raised a country's likelihood to slide into a currency crisis.

\section{Conclusion}

Corruption affects the composition of capital inflows in a way that is not favorable to the country. A corrupt country receives substantially less foreign direct investment. However, it may not be as much disadvantaged in obtaining bank loans. As a result, corruption in a capital-importing country tends to tilt the composition of its capital inflows away from foreign direct investment and towards foreign bank loans. The data supports this hypothesis. This result is robust across different measures of corruption and different econometric specifications.

There are two possible reasons for this effect. First, foreign direct investments are more likely to be exploited by local corrupt officials ex post than foreign loans. As a 
result, less FDI would go to corrupt countries ex ante. Second, the current international financial architecture is such that there is more insurance/protection from the IMF and the G7 governments for bank lenders from developed countries than for direct investors.

Previous research (starting with Frankel and Rose, 1996) has shown that a capital inflow structure that is relatively low in FDI is associated with a greater propensity for a future currency crisis. It may be that international bank loans (or other portfolio flows) swing more than direct investment in the event of bad news (real, or self-generated by international investors) about economic or policy fundamentals. If so, this paper has provided evidence for one possible channel through which corruption in a developing country may increase its chances of running into a future crisis.

In the literature on the causes of currency crises, crony capitalism and selffulfilling expectations by international creditors are often proposed as two rival hypotheses. Indeed, authors that subscribe to one view often do not accept the other. The evidence in this paper suggests a natural linkage between the two. Crony capitalism, through its effect on the composition of a country's capital inflows, makes it more vulnerable to the self-fulfilling expectations-type of currency crisis.

Corruption could also lead to a financial crisis by weakening domestic financial supervision and producing a deteriorated quality of banks' and firms' balance sheets. This possibility itself can be a topic for a useful research project. 


\section{References:}

Ades, Alberto, and Rafael di Tella, 1997, "National Champions and Corruption: Some Unpleasant Interventionist Arithmetic,” The Economic Journal, Vol.107(443): 1023-42, July.

Bai, Chong-En, and Shang-Jin Wei, 2000, "Quality of Bureaucracy and OpenEconomy Macro Policies,” NBER Working Paper No. 7766, June.

Bardhan, Pranab, 1997, "Corruption and Development: A Review of Issues," Journal of Economic Literature, Vol. XXXV (September): 1320-1346.

Borensztein, E., J. De Gregorio, and J-W Lee, 1995, "How Does Foreign Direct Investment Affect Economic Growth," NBER Working Paper No. 5057.

Dooley, M.P., S. Claessens, and A. Warner, 1995, "Portfolio Capital Flows: Hot or Cool?" World Bank Economic Review, 9(1): 53-174. Reprinted in Mike J. Howell, edited, 1996, Investing in Emerging Markets, London, UK: Eurocurrency Publications.

Eaton, Jonathan, and Akiko Tamura, 1996, "Japanese and U.S. Exports and Investment as Conducts of Growth," NBER Working Paper 5457.

Frankel and Rose, 1996, "Currency Crashes in Emerging Markets: An Empirical Treatment," Journal of International Economics, v41 n3-4 (November): 351-66.

Hausmann, Ricardo and Eduardo Fernandez-Arias, 2000, "Foreign Direct Investment: Good Cholesterol?" Inter-American Development Bank working paper \#417, March 26, 2000.

Hausmann, Ricardo, Ugo Panizza, and Ernesto Stein, 2000, "Why Do Countries Float the Way They Float?" Inter-American Development Bank working paper.

Hines, James, 1995, "Forbidden Payment: Foreign Bribery and American Business After 1977," NBER Working Paper 5266, September.

International Monetary Fund, Balance of Payments Statistics, various issues.

Johnson, Simon, Peter Boone, Alasdair Breach, and Eric Friedman, 2000, "Corporate Governance in the Asian Financial Crisis," Journal of Financial Economics 58(1-2): 141-86.

Kaufmann, Daniel, 1997, “Corruption: some Myths and Facts,” Foreign Policy, Summer: 114-131. 
Kaufmann, Daniel and Shang-Jin Wei, 1999, “Does 'Grease Payment' Speed Up the Wheels of Commerce?" National Bureau of Economic Research Working Paper 7093.

La Porta, Rafael, Florencio Lopez-de-Silanes, Andrei Shleifer, and Robert Vishny, 1998, “Law and Finance," Journal of Political Economy 106: 1113-1155.

La Porta, Rafael, Florencio Lopez-de-Silanes, Andrei Shleifer, and Robert Vishny, 1999, "The quality of government," Journal of Law, Economics and Organization, (15): 222-279.

Mauro, Paolo, 1995, "Corruption and Growth, "Quarterly Journal of Economics, 110: 681-712.

McKinnon, Ronald, and Huw Pill, 1996, "Credible Liberalization and International Capital Flows: The Overborrowing Syndrome," in Takatoshi Ito and Anne O. Krueger eds., Financial Deregulation and Integration in East Asia, Chicago: University of Chicago Press, pp 7-45.

McKinnon, Ronald, and Huw Pill, 1999, "Exchange Rate Regimes for Emerging Markets: Moral Hazard and International Overborrowing," Stanford University and Harvard University. Forthcoming, Oxford Review of Economic Policy.

Neumann, P. 1994, “Bose: fast alle bestechen,” Impulse, Hamburg: Gruner + Jahr AG\&Co, pp. 12-6.

OECD, 1999, International Direct Investment Statistics Yearbook, Paris: OECD Publication. [There is an associated data diskette.]

Pearce, E.A. and C.G.Smith, 1984, "The World Weather Guide," Hutchinson, London.

PricewaterhouseCoopers, 2000, Doing Business and Investing Worldwide, (in CD-Rom).

Radelet, Steven, and Jeffrey Sachs, 1998, "The East Asian Financial Crisis: Diagnosis, Remedies, and Prospects, “ Brookings Papers on Economic Activities. Razin, Assaf, Efraim Sadka, and Chi-Wa Yuen, 1998, “A Pecking Order of Capital Inflows and International Tax Principles," Journal of International Economics, 44.

Reisen, Helmut, 1999, “The Great Asian Slump,” OECD Development Center. 
Rodrik, Dani, and Andres Velasco, 1999, "Short-Term Capital Flows," Paper prepared for the 1999 World Bank Annual Bank Conference on Development Economics. Harvard University and New York University.

Rudloff, Willy, 1981, "World-climates, with tables of climatic data and practical suggestions," Wissenschaftliche Verlagsgesellschaft, Stuttgart.

Shleifer, Andrei, and Robert Vishny, 1993, "Corruption," Quarterly Journal of Economics 108, 599-617.

Smarzynska, Beata, and Shang-Jin Wei, 2000, "Corruption and the Composition of Foreign Direct Investment: Firm-level Evidence," the National Bureau of Economic Research Working Paper 7969.

Tornell, Aaron, 1990, "Real vs. Financial Investment: Can Tobin Taxes Eliminate the Irreversibility Distortion?" Journal of Development Economics 32: 419444.

UNCTAD (United Nations Conference on Trade and Development), 1998, World Investment Report, New York and Geneva.

Wei, Shang-Jin, 1997, "Why is Corruption So Much More Taxing Than Taxes? Arbitrariness Kills, "NBER Working Paper 6255, November.

Wei, Shang-Jin, 1999, "Corruption in Economic Development: Beneficial Grease, Minor Annoyance, or Major Obstacle?” The World Bank Policy Research Working Paper, 2048, February.

Wei, Shang-Jin, 2000a, "How Taxing is Corruption on International Investors?" Review of Economics and Statistics, February, 82(1): 1-11.

Wei, Shang-Jin, 2000b, "Why Does China Attract So Little Foreign Direct Investment?" in Takatoshi Ito and Anne O. Krueger, eds., The Role of Foreign Direct Investment in East Asian Economic Development, Chicago and London: University of Chicago Press, pp239-261.

Wei, Shang-Jin, 2000c, "Local Corruption and Global Capital Flows," Brookings Papers on Economic Activity, 2000(2).

Wei, Shang-Jin, 2000d, "Natural Openness and Good Government," NBER Working Paper 7765, June. 
Table 1a: Volatility of FDI/GDP, Bank Loan/GDP, and Portfolio Flow/GDP as Measured by Standard Deviation:1980-1996

FDI/GDP Loan/GDP Portfolio/GDP

\begin{tabular}{llll} 
Whole sample: $\mathbf{1 0 3}$ countries & & & \\
Mean & 0.012 & 0.041 & 0.014 \\
Median & 0.008 & 0.033 & 0.009 \\
Emerging markets: 85 countries & & & \\
Mean & 0.012 & 0.046 & 0.012 \\
Median & 0.008 & 0.035 & 0.004 \\
& & & \\
OECD: 18 countries & & & \\
Mean & 0.008 & 0.020 & 0.021 \\
Median & 0.007 & 0.014 & 0.020 \\
& & & \\
Selected countries & & & \\
Indonesia & 0.007 & 0.017 & 0.009 \\
Korea & 0.002 & 0.037 & 0.014 \\
Malaysia & 0.023 & 0.034 & 0.023 \\
Mexico & 0.007 & 0.033 & 0.026 \\
Philippines & 0.009 & 0.026 & 0.017 \\
Thailand & 0.007 & 0.028 & 0.012 \\
\hline
\end{tabular}

Notes:

1. Sources: Total inward FDI flows, total bank loans, and total inward portfolio investments are from the IMF's Balance of Payment Statistics, various issues, GDP data are from the World Bank's GDF \& WDI Central Databases.

2. Only countries that have at least eight non-missing observations during 1980-1996 for all three variables and whose populations are greater than or equal to one million in 1995 are kept in the sample.

3. OECD countries (with membership up to 1980) include: Australia, Austria, Canada, Denmark, Finland, France, Ireland, Italy, Japan, Netherlands, New Zealand, Norway, Portugal, Spain, Sweden, Switzerland, United Kingdom, United States. Emerging Markets refer to all countries not on the above list and with a GDP per capita in 1995 less than or equal to US\$15,000 (in 1995 U.S. \$). 
Table 1b: Volatility of FDI/GDP, Bank Loan/GDP, and Portfolio Flow/GDP as Measured by Coefficient of Variation: 1980-1996

\section{FDI/GDP Loan/GDP Portfolio/GDP}

\begin{tabular}{lccc} 
Whole sample: $\mathbf{1 0 3}$ countries & & & \\
Mean & 1.176 & 1.567 & 2.764 \\
Median & 0.947 & 1.204 & 1.702 \\
& & & \\
Emerging markets: $\mathbf{8 5}$ countries & & & \\
Mean & 1.269 & 2.192 & 0.813 \\
Median & 1.163 & 1.177 & 2.042 \\
& & & \\
OECD: 18 countries & & & \\
Mean & 0.737 & -1.353 & 8.508 \\
Median & 0.595 & 1.530 & 1.004 \\
& & & \\
Selected countries & & & \\
Indonesia & 0.820 & 0.717 & 1.722 \\
Korea & 0.591 & 2.039 & 1.338 \\
Malaysia & 0.490 & 4.397 & 3.544 \\
Mexico & 0.452 & 2.048 & 2.088 \\
Philippines & 0.921 & 0.956 & 1.979 \\
Thailand & 0.571 & 0.629 & 1.137 \\
\hline
\end{tabular}

Notes:

(a) See the notes to Table 1a.

(b) In the case of the volatility of the loan/GDP ratio for the OECD countries, the big difference between the mean and median (-1.35 vs. 1.53) is driven by one outlier (Japan, with a value of -49). 
Table 2: Quality of Public Governance and the Composition of Capital Inflows

\begin{tabular}{lcccc}
\hline & New Zealand & Singapore & Uruguay & Thailand \\
$\begin{array}{l}\text { Corruption } \\
\text { (Ti Index) }\end{array}$ & 0.6 & 0.9 & 5.7 & $\begin{array}{c}7.0 \\
\text { (less corrupt) }\end{array}$ \\
(more corrupt)
\end{tabular}

1. Source: Total inward loans, portfolio investment, and FDI are from the IMF's Balance of Payment Statistics. To minimize the impact of the year-to-year fluctuation, the reported numbers are averaged over 1994-96. The corruption index is explained in the data appendix.

2. The lower half of the table reports the absolute amount of the three inflows in millions of US dollars. 
Table 3: List of Countries in the Sample

\section{Bilateral Foreign Direct Investment}

\section{Source countries:}

Australia, Austria, Canada, Finland, France, Germany, Iceland, Italy, Japan, Korea, Netherlands, New Zealand, Norway, Poland, Sweden, Switzerland, United Kingdom, United States

\section{Host countries:}

Algeria, Argentina, Australia, Austria, Belgium-Luxembourg, Brazil, Bulgaria, Canada, Chile, China, Colombia, Costa Rica, Czech Republic, Denmark, Egypt, Finland, France, Germany, Greece, Hong Kong, Hungary, Iceland, India, Indonesia, Iran, Ireland, Israel, Italy, Japan, Korea, Kuwait, Libya, Malaysia, Mexico, Morocco, Netherlands, New Zealand, Norway, Panama, Philippines, Poland, Portugal, Romania, Russian Federation, Saudi Arabia, Singapore, Slovak Republic, Slovenia, South Africa, Spain, Sweden, Switzerland, Taiwan, Thailand, Turkey, Ukraine, United Arab Emirates, United Kingdom, United States, Venezuela

\section{Bilateral International Bank Loans}

\section{Lending countries:}

Austria, Belgium, Canada, Finland, France, Germany, Italy, Japan, Luxembourg, Netherlands, Spain, United Kingdom, United States

\section{Borrowing countries:}

Albania, Argentina, Armenia, Australia, Azerbaijan, Belarus, Benin, Bolivia, Brazil, Bulgaria, , Cameroon, Chad, Chile, China, Colombia, Congo, Rep., Costa Rica, Cote d' Ivoire, Czech Republic, Ecuador, Egypt, Arab Rep., El Salvador, Estonia, Fiji, Georgia, Ghana, Greece, Guatemala, Guinea, Guinea-Bissau, Honduras, Hungary, Iceland, India, Indonesia, Islamic Rep., Israel, Jamaica, Jordan, Kazakhstan, Kenya, Korea, Rep., Kyrgyz Republic, Latvia, Lithuania, Madagascar, Malawi, Malaysia, Mali, Mauritius, Mexico, Moldova, Morocco, Mozambique, Namibia, New Zealand, Nicaragua, Niger, Nigeria, Pakistan, Paraguay, Peru, Philippines, Poland, Portugal, Romania, Russian Federation, Senegal, Slovak Republic, South Africa, Taiwan, Tanzania, Thailand, Tonga, Tunisia, Turkey, Uganda, Ukraine, Uruguay, Uzbekistan, Venezuela, Vietnam, Zambia, Zimbabwe 
Table 4a. Summary Statistics

\begin{tabular}{lccccc}
\hline Variable & Obs. & Mean & Std. Dev. & Min & Max \\
\hline Corruption: GCR/WDR combined & 99 & 3.62 & 1.19 & 1.3 & 5.5 \\
Corruption: Transparency International & 85 & 5.12 & 2.40 & 0 & 8.6 \\
Tax rate (Highest corporate income tax rate) & 56 & 32.39 & 6.86 & 0 & 42 \\
FDI incentives & 49 & 1.65 & 0.69 & 0 & 3 \\
FDI restrictions & 49 & 1.69 & 1.18 & 0 & 4 \\
Per capita GDP, 94-96 & 154 & 5792 & 9222 & 104 & 43602 \\
Ln(Loan/FDI), bilateral 94-96 & 288 & 1.53 & 2.21 & -8.06 & 8.75 \\
Ln(Loan/FDI), balance of payment, 94-96 & 125 & 0.31 & 2.00 & -4.84 & 6.18 \\
Ln(Portfolio/FDI), balance of payment, 94-96 & 89 & -0.66 & 1.98 & -5.28 & 5.77 \\
\hline
\end{tabular}

Table 4b: Correlation Matrix

\begin{tabular}{|l|c|c|c|c|}
\hline & \multirow{2}{*}{$\begin{array}{c}\text { GDP } \\
\text { per capita }\end{array}$} & \multicolumn{3}{|c|}{ Corruption } \\
\cline { 3 - 5 } & & TI & GCR & WDR \\
\cline { 3 - 5 } & & & & \\
\hline GDP per capita & 1 & & & \\
\hline Corruption-TI & -0.82 & 1 & & \\
\hline Corruption-GCR & -0.78 & 0.87 & 1 & \\
\hline Corruption-WDR & -0.72 & 0.86 & 0.83 & 1 \\
\hline
\end{tabular}


Table 5: Corruption and Foreign Direct Investment

\begin{tabular}{|c|c|c|c|c|}
\hline Methodology & $\begin{array}{l}\text { Fixed } \\
\text { Effects }\end{array}$ & $\begin{array}{c}\text { Random } \\
\text { Effects }\end{array}$ & $\begin{array}{c}\text { Fixed } \\
\text { Effects }\end{array}$ & $\begin{array}{c}\text { Random } \\
\text { Effects }\end{array}$ \\
\hline Measure of corruption & \multicolumn{2}{|c|}{ GCR/WDR } & \multicolumn{2}{|c|}{ TI } \\
\hline Corruption & $\begin{array}{c}-0.427^{* *} \\
(0.103)\end{array}$ & $\begin{array}{c}-0.407^{* *} \\
(0.168)\end{array}$ & $\begin{array}{c}-0.502^{* \star} \\
(0.111)\end{array}$ & $\begin{array}{c}-0.508^{* *} \\
(0.183)\end{array}$ \\
\hline Tax rate & $\begin{array}{l}-0.031^{* *} \\
(0.011)\end{array}$ & $\begin{array}{l}-0.034^{*} \\
(0.019)\end{array}$ & $\begin{array}{r}-0.030^{* *} \\
(0.011)\end{array}$ & $\begin{array}{l}-0.034^{*} \\
(0.019)\end{array}$ \\
\hline FDI incentives & $\begin{array}{l}0.403^{\star *} \\
(0.095)\end{array}$ & $\begin{array}{l}0.324^{\star *} \\
(0.162)\end{array}$ & $\begin{array}{l}0.400^{* *} \\
(0.095)\end{array}$ & $\begin{array}{l}0.345^{\star *} \\
(0.157)\end{array}$ \\
\hline FDI restrictions & $\begin{array}{l}-0.335^{\star *} \\
(0.058)\end{array}$ & $\begin{array}{l}-0.323^{* *} \\
(0.098)\end{array}$ & $\begin{array}{r}-0.324^{\star *} \\
(0.058)\end{array}$ & $\begin{array}{l}-0.308^{\star *} \\
(0.096)\end{array}$ \\
\hline $\log (G D P)$ & $\begin{array}{l}0.857^{\star \star} \\
(0.053)\end{array}$ & $\begin{array}{l}0.942^{\star *} \\
(0.091)\end{array}$ & $\begin{array}{l}0.909^{* *} \\
(0.055)\end{array}$ & $\begin{array}{l}0.994^{\star *} \\
(0.091)\end{array}$ \\
\hline Log (Per capita GDP) & $\begin{array}{l}-0.039 \\
(0.086)\end{array}$ & $\begin{array}{l}-0.121 \\
(0.143)\end{array}$ & $\begin{array}{l}-0.125 \\
(0.096)\end{array}$ & $\begin{array}{l}-0.218 \\
(0.158)\end{array}$ \\
\hline Log distance & $\begin{array}{c}-0.555^{\star *} \\
(0.060)\end{array}$ & $\begin{array}{c}-0.856^{\star *} \\
(0.067)\end{array}$ & $\begin{array}{c}-0.557^{\star *} \\
(0.060)\end{array}$ & $\begin{array}{c}-0.844^{* *} \\
(0.067)\end{array}$ \\
\hline Linguistic tie & $\begin{array}{l}1.426^{\star *} \\
(0.211)\end{array}$ & $\begin{array}{l}1.041^{* *} \\
(0.194)\end{array}$ & $\begin{array}{l}1.409^{* *} \\
(0.210)\end{array}$ & $\begin{array}{l}1.049^{* *} \\
(0.195)\end{array}$ \\
\hline Exchange rate volatility & $\begin{array}{c}0.053 \\
(1.968)\end{array}$ & $\begin{array}{l}-2.752 \\
(3.033)\end{array}$ & $\begin{array}{c}0.210 \\
(1.960)\end{array}$ & $\begin{array}{l}-2.354 \\
(2.954)\end{array}$ \\
\hline $\begin{array}{l}\text { Adjusted } \mathrm{R}^{2} / \text { Over-all } \mathrm{R}^{2} \\
\text { No. of obs. }\end{array}$ & $\begin{array}{l}0.74 \\
628\end{array}$ & $\begin{array}{l}0.74 \\
628\end{array}$ & $\begin{array}{l}0.74 \\
628 \\
\end{array}$ & $\begin{array}{l}0.74 \\
628 \\
\end{array}$ \\
\hline
\end{tabular}

Notes:

$1 . * *, *$ and \# indicate significant at the 5\%,10\%, and $15 \%$ levels, respectively. Standard errors are in parentheses.

2. Fixed-effects regression: $\log \mathrm{FDI}(\mathrm{k}, \mathrm{j})=$ source country dummies $+\mathrm{b} X(\mathrm{k}, \mathrm{j})+\mathrm{e}(\mathrm{k}, \mathrm{j})$; where FDI(k,j) is FDI from source country $\mathrm{k}$ to host country $\mathrm{j}$. All regressions include source country dummies whose coefficients are not reported to save space.

3. Random-effects specification: $Y(k, j)=$ source country dummies $+b X(k, j)+u(j)+e(k, j)$, where $u(j)$ is the host-country random effect.

4. $\log (\mathrm{FDI}), \log (\mathrm{GDP})$ and $\log ($ per capita GDP) are averaged over 1994-1996. Exchange rate volatility $=$ standard deviation of the first difference in log monthly exchange rate (per US\$) over 1994:1-1996:12. 5. Corruption measure is standardized [i.e., corruption in the regressions $=$ (original corruption - sample mean $) /($ sample standard deviation)]. Hence, the coefficient on corruption can be read as the response of the 
left-hand-side variable with respect to a one-standard-deviation increase in corruption. 
Table 6: Corruption and Bank Lending

\begin{tabular}{|c|c|c|c|c|}
\hline & $\begin{array}{l}\text { Fixed } \\
\text { Effects }\end{array}$ & $\begin{array}{l}\text { Random } \\
\text { Effects }\end{array}$ & $\begin{array}{l}\text { Fixed } \\
\text { Effects }\end{array}$ & $\begin{array}{c}\text { Random } \\
\text { Effects }\end{array}$ \\
\hline Measure of corruption & \multicolumn{2}{|c|}{ GCR/ WDR } & \multicolumn{2}{|c|}{ T I } \\
\hline Corruption & $\begin{array}{l}0.376^{\star *} \\
(0.092)\end{array}$ & $\begin{array}{l}0.390^{\star *} \\
(0.120)\end{array}$ & $\begin{array}{l}0.197 \# \\
(0.127)\end{array}$ & $\begin{array}{c}0.135 \\
(0.166)\end{array}$ \\
\hline $\begin{array}{l}\text { Ease in investing in } \\
\text { securities and bonds market }\end{array}$ & $\begin{array}{l}0.219^{\star \star} \\
(0.088)\end{array}$ & $\begin{array}{l}0.262^{\star \star} \\
(0.115)\end{array}$ & $\begin{array}{c}0.110 \\
(0.089)\end{array}$ & $\begin{array}{c}0.161 \\
(0.116)\end{array}$ \\
\hline $\log (\mathrm{GDP})$ & $\begin{array}{l}1.004^{\star *} \\
(0.054)\end{array}$ & $\begin{array}{l}1.054^{\star *} \\
(0.068)\end{array}$ & $\begin{array}{l}0.984^{* *} \\
(0.060)\end{array}$ & $\begin{array}{l}1.052^{* *} \\
(0.076)\end{array}$ \\
\hline Log (Per capita GDP) & $\begin{array}{l}0.366^{\star *} \\
(0.063)\end{array}$ & $\begin{array}{l}0.356^{\star *} \\
(0.081)\end{array}$ & $\begin{array}{l}0.388^{\star *} \\
(0.096)\end{array}$ & $\begin{array}{l}0.337^{\star *} \\
(0.125)\end{array}$ \\
\hline Log distance & $\begin{array}{l}-0.244^{* *} \\
(0.072)\end{array}$ & $\begin{array}{c}-0.428^{\star *} \\
(0.082)\end{array}$ & $\begin{array}{c}-0.224^{* *} \\
(0.076)\end{array}$ & $\begin{array}{c}-0.432^{\star *} \\
(0.085)\end{array}$ \\
\hline Linguistic tie & $\begin{array}{l}0.633^{\star *} \\
(0.207)\end{array}$ & $\begin{array}{l}0.818^{\star \star} \\
(0.198)\end{array}$ & $\begin{array}{l}0.556^{\star \star} \\
(0.210)\end{array}$ & $\begin{array}{l}0.776^{* *} \\
(0.200)\end{array}$ \\
\hline Exchange rate volatility & $\begin{array}{l}-5.917^{\star *} \\
(1.564)\end{array}$ & $\begin{array}{l}-7.253^{* *} \\
(1.966)\end{array}$ & $\begin{array}{l}-5.359^{\star *} \\
(1.618)\end{array}$ & $\begin{array}{l}-6.598^{\star *} \\
(2.060)\end{array}$ \\
\hline $\begin{array}{l}\text { Adjusted } \mathrm{R}^{2} / \text { Over-all } \mathrm{R}^{2} \\
\text { No. of observations. }\end{array}$ & $\begin{array}{l}0.72 \\
396\end{array}$ & $\begin{array}{l}0.73 \\
396\end{array}$ & $\begin{array}{l}0.71 \\
396\end{array}$ & $\begin{array}{l}0.72 \\
396\end{array}$ \\
\hline
\end{tabular}

Note: see notes to Table 5. 


\section{Table 7: Composition of Capital Flows}

\begin{tabular}{|c|c|c|c|c|c|c|}
\hline \multicolumn{7}{|c|}{ Dependent variable: $\log ($ Loan $)-\log ($ FDI $)$, averaged over 1994-96 } \\
\hline Methodology & $\begin{array}{l}\text { Fixed } \\
\text { Effects } \\
\text { GCR }\end{array}$ & $\begin{array}{l}\text { Random } \\
\text { Effects } \\
\text { NDR }\end{array}$ & $\begin{array}{l}\text { Fixed } \\
\text { Effects }\end{array}$ & $\begin{array}{l}\text { Random } \\
\text { Effects }\end{array}$ & $\begin{array}{r}\text { Fixed } \\
\text { GCR }\end{array}$ & $\begin{array}{l}\text { fects } \\
\text { NDR }\end{array}$ \\
\hline Corruption & $\begin{array}{l}0.662^{* *} \\
(0.128)\end{array}$ & $\begin{array}{l}0.680^{* *} \\
(0.225)\end{array}$ & $\begin{array}{l}0.707^{\star *} \\
(0.176)\end{array}$ & $\begin{array}{l}0.720^{* *} \\
(0.290)\end{array}$ & $\begin{array}{l}0.296 \# \\
(0.181)\end{array}$ & $\begin{array}{l}0.285 \# \\
(0.182)\end{array}$ \\
\hline Tax rate & $\begin{array}{c}0.021 \\
(0.017)\end{array}$ & $\begin{array}{c}0.021 \\
(0.031)\end{array}$ & $\begin{array}{c}0.021 \\
(0.018)\end{array}$ & $\begin{array}{c}0.020 \\
(0.029)\end{array}$ & & \\
\hline FDI incentives & $\begin{array}{c}0.194 \\
(0.152)\end{array}$ & $\begin{array}{c}0.244 \\
(0.260)\end{array}$ & $\begin{array}{l}-0.056 \\
(0.160)\end{array}$ & $\begin{array}{l}-0.019 \\
(0.254)\end{array}$ & $\begin{array}{c}0.111 \\
(0.156)\end{array}$ & $\begin{array}{c}0.095 \\
(0.157)\end{array}$ \\
\hline FDI restrictions & $\begin{array}{l}0.440^{\star *} \\
(0.086)\end{array}$ & $\begin{array}{l}0.446^{\star *} \\
(0.157)\end{array}$ & $\begin{array}{l}0.458^{\star *} \\
(0.088)\end{array}$ & $\begin{array}{l}0.446^{* *} \\
(0.145)\end{array}$ & $\begin{array}{l}0.336^{\star \star} \\
(0.093)\end{array}$ & $\begin{array}{l}0.333^{* *} \\
(0.093)\end{array}$ \\
\hline $\log (\mathrm{GDP})$ & $\begin{array}{c}-0.569^{* *} \\
(0.107)\end{array}$ & $\begin{array}{l}-0.651^{\text {** }} \\
(0.186)\end{array}$ & $\begin{array}{c}-0.597^{* *} \\
(0.110)\end{array}$ & $\begin{array}{c}-0.655^{\star *} \\
(0.174)\end{array}$ & $\begin{array}{c}-0.274^{* *} \\
(0.115)\end{array}$ & $\begin{array}{c}-0.254^{* *} \\
(0.118)\end{array}$ \\
\hline Log (Per capita GDP) & $\begin{array}{l}0.172^{*} \\
(0.098)\end{array}$ & $\begin{array}{c}0.205 \\
(0.181)\end{array}$ & $\begin{array}{l}0.272^{\star *} \\
(0.125)\end{array}$ & $\begin{array}{c}0.302 \\
(0.210)\end{array}$ & $\begin{array}{c}0.034 \\
(0.103)\end{array}$ & $\begin{array}{c}0.033 \\
(0.103)\end{array}$ \\
\hline Log distance & $\begin{array}{l}0.350^{\star *} \\
(0.094)\end{array}$ & $\begin{array}{l}0.543^{* *} \\
(0.114)\end{array}$ & $\begin{array}{l}0.357^{\star *} \\
(0.096)\end{array}$ & $\begin{array}{l}0.525^{\star *} \\
(0.114)\end{array}$ & $\begin{array}{c}0.123 \\
(0.132)\end{array}$ & $\begin{array}{c}0.111 \\
(0.132)\end{array}$ \\
\hline Linguistic tie & $\begin{array}{c}-0.699^{* *} \\
(0.305)\end{array}$ & $\begin{array}{c}-0.680^{* *} \\
(0.287)\end{array}$ & $\begin{array}{c}-0.722^{* *} \\
(0.313)\end{array}$ & $\begin{array}{c}-0.700^{* *} \\
(0.292)\end{array}$ & $\begin{array}{c}-0.753^{* *} \\
(0.289)\end{array}$ & $\begin{array}{c}-0.803^{* *} \\
(0.296)\end{array}$ \\
\hline Exchange rate volatility & $\begin{array}{l}-0.661 \\
(2.060)\end{array}$ & $\begin{array}{l}-0.007 \\
(3.505)\end{array}$ & $\begin{array}{l}-1.351 \\
(2.216)\end{array}$ & $\begin{array}{l}-0.755 \\
(3.488)\end{array}$ & & $\begin{array}{l}-1.793 \\
(2.226)\end{array}$ \\
\hline $\begin{array}{l}\text { Over-identifying restriction } \\
\text { (P-value of the test) } \\
\text { Adjusted } \mathrm{R}^{2} / \text { Over-all } \mathrm{R}^{2} \\
\text { No. of obs. }\end{array}$ & $\begin{array}{l}0.49 \\
225\end{array}$ & $\begin{array}{l}0.52 \\
225\end{array}$ & $\begin{array}{l}0.46 \\
225\end{array}$ & $\begin{array}{l}0.50 \\
225\end{array}$ & $\begin{array}{c}- \\
180\end{array}$ & $\begin{array}{c}- \\
180\end{array}$ \\
\hline
\end{tabular}

Note: see notes to Table 5. 
Table 8: Transformed Ratio of Loans to FDI

\begin{tabular}{|c|c|c|c|c|c|c|}
\hline \multicolumn{7}{|c|}{ Dependent variable: $\log (\operatorname{Loan}+0.1)-\log (\mathrm{FDI}+0.1)$, averaged over 1994-96 } \\
\hline Methodology & $\begin{array}{c}\text { Fixed } \\
\text { Effects } \\
\text { GCR }\end{array}$ & $\begin{array}{l}\text { Random } \\
\text { Effects } \\
\text { NDR }\end{array}$ & $\begin{array}{l}\text { Fixed } \\
\text { Effects }\end{array}$ & $\begin{array}{c}\text { Random } \\
\text { Effects }\end{array}$ & $\begin{array}{r}\text { Fixed } \\
\text { GCR }\end{array}$ & $\begin{array}{l}\text { fects } \\
\text { NDR }\end{array}$ \\
\hline Corruption & $\begin{array}{l}0.675^{\star *} \\
(0.151)\end{array}$ & $\begin{array}{l}0.674^{\star *} \\
(0.226)\end{array}$ & $\begin{array}{l}0.701^{* *} \\
(0.210)\end{array}$ & $\begin{array}{l}0.681^{* *} \\
(0.320)\end{array}$ & $\begin{array}{l}0.382^{*} \\
(0.199)\end{array}$ & $\begin{array}{l}0.374^{*} \\
(0.196)\end{array}$ \\
\hline Tax rate & $\begin{array}{c}0.011 \\
(0.020)\end{array}$ & $\begin{array}{c}0.013 \\
(0.031)\end{array}$ & $\begin{array}{c}0.012 \\
(0.021)\end{array}$ & $\begin{array}{c}0.012 \\
(0.032)\end{array}$ & & \\
\hline FDI incentives & $\begin{array}{c}0.040 \\
(0.178)\end{array}$ & $\begin{array}{c}0.072 \\
(0.262)\end{array}$ & $\begin{array}{l}-0.196 \\
(0.187)\end{array}$ & $\begin{array}{l}-0.166 \\
(0.280)\end{array}$ & $\begin{array}{c}-0.014 \\
(0.171)\end{array}$ & $\begin{array}{l}-0.023 \\
(0.169)\end{array}$ \\
\hline FDI restrictions & $\begin{array}{l}0.546^{\star \star} \\
(0.101)\end{array}$ & $\begin{array}{l}0.550^{\star *} \\
(0.156)\end{array}$ & $\begin{array}{l}0.558^{\star *} \\
(0.103)\end{array}$ & $\begin{array}{l}0.547^{\star *} \\
(0.159)\end{array}$ & $\begin{array}{l}0.427^{\star \star} \\
(0.103)\end{array}$ & $\begin{array}{l}0.425^{\star \star} \\
(0.102)\end{array}$ \\
\hline $\log (\mathrm{GDP})$ & $\begin{array}{c}-0.591^{\star *} \\
(0.128)\end{array}$ & $\begin{array}{c}-0.645^{\star \star} \\
(0.189)\end{array}$ & $\begin{array}{c}-0.615^{* *} \\
(0.131)\end{array}$ & $\begin{array}{c}-0.657^{\star *} \\
(0.194)\end{array}$ & $\begin{array}{c}-0.323^{\star *} \\
(0.128)\end{array}$ & $\begin{array}{c}-0.309^{\star *} \\
(0.129)\end{array}$ \\
\hline Log (Per capita GDP) & $\begin{array}{l}0.227^{*} \\
(0.117)\end{array}$ & $\begin{array}{c}0.239 \\
(0.182)\end{array}$ & $\begin{array}{l}0.314^{\star *} \\
(0.149)\end{array}$ & $\begin{array}{c}0.318 \\
(0.232)\end{array}$ & $\begin{array}{c}0.114 \\
(0.114)\end{array}$ & $\begin{array}{c}0.113 \\
(0.112)\end{array}$ \\
\hline Log distance & $\begin{array}{l}0.391^{\star *} \\
(0.112)\end{array}$ & $\begin{array}{l}0.477^{\star \star} \\
(0.133)\end{array}$ & $\begin{array}{l}0.396^{* *} \\
(0.115)\end{array}$ & $\begin{array}{l}0.479^{* *} \\
(0.135)\end{array}$ & $\begin{array}{c}0.159 \\
(0.147)\end{array}$ & $\begin{array}{c}0.151 \\
(0.146)\end{array}$ \\
\hline Linguistic tie & $\begin{array}{l}-0.490 \\
(0.365)\end{array}$ & $\begin{array}{l}-0.504 \\
(0.356)\end{array}$ & $\begin{array}{l}-0.513 \\
(0.373)\end{array}$ & $\begin{array}{c}-0.522 \# \\
(0.360)\end{array}$ & $\begin{array}{l}-0.752^{\star *} \\
(0.325)\end{array}$ & $\begin{array}{c}-0.787^{* *} \\
(0.326)\end{array}$ \\
\hline Exchange rate volatility & $\begin{array}{c}0.563 \\
(2.368)\end{array}$ & $\begin{array}{c}1.091 \\
(3.490)\end{array}$ & $\begin{array}{l}-0.279 \\
(2.553)\end{array}$ & $\begin{array}{c}0.442 \\
(3.798)\end{array}$ & & $\begin{array}{l}-1.257 \\
(2.451)\end{array}$ \\
\hline $\begin{array}{l}\text { Over-identifying restriction } \\
\text { (P-value of the test) } \\
\text { Adjusted } \mathrm{R}^{2} / \text { Over-all } \mathrm{R}^{2} \\
\text { No. of obs. }\end{array}$ & $\begin{array}{l}0.48 \\
231\end{array}$ & $\begin{array}{l}0.51 \\
231\end{array}$ & $\begin{array}{l}0.45 \\
231\end{array}$ & $\begin{array}{l}0.50 \\
231\end{array}$ & $\begin{array}{c}- \\
183\end{array}$ & $\begin{array}{c}- \\
183\end{array}$ \\
\hline
\end{tabular}

Note: see notes to Table 5. 


\section{Table 9: US-bilateral Portfolio Data}

\begin{tabular}{|c|c|c|c|c|c|c|}
\hline Dependent variable: $\log ($ port & lio inve & nent) -1 & $(\mathrm{FDI}), \mathrm{a}$ & raged ov & $1994-9$ & \\
\hline Measure of corruption & & GCR/WDF & & & $\mathrm{TI}$ & \\
\hline Corruption & $0.321^{*}$ & $0.319^{*}$ & $0.341 \#$ & 0.283 & 0.324 & 0.307 \\
\hline & $(0.173)$ & $(0.171)$ & $(0.208)$ & $(0.247)$ & $(0.270)$ & $(0.275)$ \\
\hline Tax rate & & & -0.023 & & & -0.033 \\
\hline & & & $(0.036)$ & & & $(0.033)$ \\
\hline FDI incentives & & & -0.218 & & & -0.215 \\
\hline & & & $(0.255)$ & & & $(0.249)$ \\
\hline FDI restrictions & & & 0.214 & & & 0.167 \\
\hline & & & $(0.156)$ & & & $(0.165)$ \\
\hline Ease in investing in & & & $0.364^{*}$ & & & 0.280 \\
\hline Securities and bonds market & & & $(0.203)$ & & & $(0.199)$ \\
\hline $\log (\mathrm{GDP})$ & $0.304^{\star *}$ & $0.311^{* *}$ & $0.371^{* *}$ & $0.289^{* *}$ & $0.287^{\star *}$ & $0.344^{* *}$ \\
\hline & $(0.138)$ & $(0.152)$ & $(0.161)$ & $(0.124)$ & $(0.137)$ & $(0.155)$ \\
\hline Log (Per capita GDP) & $0.506^{\star *}$ & $0.517^{* *}$ & $0.441^{* *}$ & $0.512^{* \star}$ & $0.557^{* *}$ & $0.461^{* *}$ \\
\hline & $(0.100)$ & $(0.100)$ & $(0.152)$ & $(0.163)$ & $(0.177)$ & $(0.202)$ \\
\hline Log distance & $-0.200^{*}$ & $-0.187 \#$ & $-0.194 \#$ & $-0.198^{* *}$ & $-0.180 \#$ & $-0.203 \#$ \\
\hline & $(0.101)$ & $(0.113)$ & $(0.129)$ & $(0.085)$ & $(0.107)$ & $(0.127)$ \\
\hline Linguistic tie & $0.870^{* *}$ & $0.814^{* *}$ & $1.004^{* *}$ & $0.853^{* *}$ & $0.797^{* *}$ & $0.984^{* *}$ \\
\hline & $(0.238)$ & $(0.251)$ & $(0.287)$ & $(0.269)$ & $(0.278)$ & $(0.294)$ \\
\hline Exchange rate volatility & & $3.515^{\star \star}$ & $3.990 \#$ & & 2.436 & 3.281 \\
\hline & & $(1.649)$ & $(2.367)$ & & $(2.254)$ & $(2.739)$ \\
\hline Government deficit & & 0.009 & 0.023 & & 0.006 & 0.005 \\
\hline & & $(0.034)$ & $(0.047)$ & & $(0.039)$ & $(0.049)$ \\
\hline Adjusted $\mathrm{R}^{2}$ & 0.52 & 0.56 & 0.60 & 0.51 & 0.54 & 0.58 \\
\hline No. of obs. & 39 & 36 & 35 & 39 & 36 & 35 \\
\hline
\end{tabular}

Notes: The portfolio and FDI values are the sum of the flows over 1994-96. Also see the notes to Table 5. 


\section{Table 10a: Corruption and Composition of Capital Inflows Based on Balance-of-payments data (1994-96)}

\begin{tabular}{|c|c|c|c|c|c|c|}
\hline Dependent variable & $\begin{array}{c}\text { Portfolio } \\
\text { /FDI }\end{array}$ & Loan/FDI & Loan/FDI & Loan/ FDI & $\begin{array}{c}\text { Portfolio } \\
\text { /FDI }\end{array}$ & Loan/FDI \\
\hline Measure of corruption & GCR/WDR & GCR/WDR & GCR/WDR & GCR/WDR & $\mathrm{TI}$ & TI \\
\hline \multirow[t]{2}{*}{ Corruption } & $1.296^{* *}$ & 0.356 & $0.702^{* *}$ & $0.669^{* *}$ & $1.046^{* \star}$ & $0.832^{*}$ \\
\hline & $(0.319)$ & $(0.417)$ & $(0.347)$ & $(0.269)$ & $(0.382)$ & $(0.428)$ \\
\hline \multirow[t]{2}{*}{ Tax rate } & 0.069 & 0.010 & 0.041 & & 0.045 & 0.001 \\
\hline & $(0.050)$ & $(0.053)$ & $(0.051)$ & & $(0.052)$ & $(0.051)$ \\
\hline \multirow[t]{2}{*}{ FDI incentives } & -0.260 & -0.562 & & & -0.263 & -0.572 \\
\hline & $(0.484)$ & $(0.582)$ & & & $(0.442)$ & $(0.506)$ \\
\hline \multirow[t]{2}{*}{ FDI restrictions } & 0.197 & 0.281 & & & 0.023 & 0.245 \\
\hline & $(0.280)$ & $(0.249)$ & & & $(0.326)$ & $(0.252)$ \\
\hline Ease in & 0.288 & & & & -0.056 & \\
\hline Portfolio investment & $(0.471)$ & & & & $(0.554)$ & \\
\hline \multirow[t]{2}{*}{$\log (\mathrm{GDP})$} & $0.559^{* *}$ & 0.414 & 0.022 & $-0.256 \#$ & $0.548^{* \star}$ & 0.332 \\
\hline & $(0.252)$ & $(0.349)$ & $(0.293)$ & $(0.165)$ & $(0.239)$ & $(0.313)$ \\
\hline \multirow[t]{2}{*}{ Log (Per capita GDP) } & $0.861^{* \star}$ & 0.314 & $0.560^{*}$ & $0.316 \#$ & $0.851^{\star *}$ & $0.641^{*}$ \\
\hline & $(0.304)$ & $(0.360)$ & $(0.283)$ & $(0.198)$ & $(0.390)$ & $(0.367)$ \\
\hline \multirow[t]{2}{*}{ Exchange rate volatility } & $-7.148 \#$ & -10.322 & -6.070 & & -5.067 & -11.410 \\
\hline & $(4.406)$ & $(12.181)$ & $(11.489)$ & & $(5.838)$ & $(11.525)$ \\
\hline Adjusted $\mathrm{R}^{2}$ & 0.51 & 0.24 & 0.13 & 0.16 & 0.46 & 0.31 \\
\hline No. of obs. & 41 & 39 & 44 & 73 & 41 & 39 \\
\hline
\end{tabular}

The let-hand-side variables are in logarithm and averaged over 1994-96. Exchange rate volatility $=$ standard deviation of the first difference in log monthly exchange rate (per US\$) over 1994:11996:12. Corruption variable is standardized (see the last footnote to Table 5). 


\section{Table 10b: Corruption and Composition of Capital Inflows based on balance-of-payments data (1997-98)}

\begin{tabular}{|c|c|c|c|c|c|c|c|c|}
\hline \multirow{2}{*}{ Dependent variable } & \multirow{2}{*}{$\begin{array}{l}\text { Portfolio/ } \\
\text { FDI } \\
\text { GCR/WDR }\end{array}$} & \multirow{2}{*}{$\begin{array}{l}\text { Loan/ } \\
\text { FDI } \\
\text { GCR/WDR }\end{array}$} & \multirow{2}{*}{$\begin{array}{c}\text { Loan/ } \\
\text { FDI } \\
\text { GCR/WDR }\end{array}$} & \multirow{2}{*}{$\begin{array}{l}\text { Portfolio/ } \\
\text { FDI } \\
\text { TI }\end{array}$} & \multirow{2}{*}{$\begin{array}{l}\text { Portfolio/ } \\
\text { FDI } \\
\text { TI }\end{array}$} & \multirow{2}{*}{$\begin{array}{l}\text { Loan/ } \\
\text { FDI } \\
\text { TI }\end{array}$} & \multicolumn{2}{|c|}{$\begin{array}{l}\mathrm{FDI} /(\mathrm{FDI}+\mathrm{loan}+ \\
\text { portfolio) }\end{array}$} \\
\hline & & & & & & & GCR/WDR & $\mathrm{Ti}$ \\
\hline \multirow[t]{2}{*}{ Measure of corruption } & $0.570^{*}$ & $0.579 \#$ & $0.600^{*}$ & 0.398 & $0.657^{*}$ & $0.725^{*}$ & $-0.374^{*}$ & $-0.481^{* *}$ \\
\hline & $(0.330)$ & $(0.385)$ & $(0.348)$ & (0.319) & (0.330) & $(0.412)$ & (0.193) & $(0.198)$ \\
\hline \multirow[t]{2}{*}{ Tax rate } & $0.102^{* *}$ & 0.041 & 0.040 & $0.090^{\star *}$ & $0.089^{* *}$ & 0.034 & $-0.045^{*}$ & $-0.041^{*}$ \\
\hline & $(0.043)$ & $(0.045)$ & $(0.044)$ & $(0.038)$ & $(0.041)$ & $(0.045)$ & $(0.024)$ & $(0.023)$ \\
\hline \multirow[t]{2}{*}{ FDI incentives } & $-0.733^{* *}$ & -0.449 & -0.461 & $-0.601^{*}$ & $-0.679^{*}$ & -0.465 & 0.030 & 0.048 \\
\hline & $(0.340)$ & $(0.366)$ & $(0.350)$ & $(0.312)$ & $(0.339)$ & $(0.362)$ & $(0.188)$ & $(0.183)$ \\
\hline \multirow[t]{2}{*}{ FDI restrictions } & 0.222 & -0.072 & -0.066 & 0.006 & 0.150 & -0.109 & 0.010 & 0.024 \\
\hline & $(0.215)$ & $(0.230)$ & $(0.224)$ & $(0.201)$ & $(0.210)$ & $(0.229)$ & $(0.117)$ & $(0.114)$ \\
\hline \multirow{2}{*}{$\begin{array}{l}\text { Ease in investing in } \\
\text { securities and bonds mkt. }\end{array}$} & 0.394 & & & $0.652 \#$ & 0.222 & & & \\
\hline & $(0.407)$ & & & $(0.405)$ & $(0.402)$ & & & \\
\hline \multirow[t]{2}{*}{$\log (\mathrm{GDP})$} & 0.071 & 0.158 & 0.152 & 0.187 & 0.059 & 0.093 & $-0.272^{* *}$ & $-0.228^{\star *}$ \\
\hline & $(0.191)$ & $(0.214)$ & $(0.207)$ & $(0.180)$ & $(0.188)$ & $(0.218)$ & $(0.100)$ & $(0.100)$ \\
\hline \multirow[t]{2}{*}{ Log (Per capita GDP) } & $0.713^{* *}$ & $0.473 \#$ & $0.479 \#$ & 0.492 & $0.849^{* *}$ & $0.610^{*}$ & $-0.350^{* *}$ & $-0.458^{\star \star}$ \\
\hline & $(0.305)$ & $(0.316)$ & $(0.308)$ & $(0.335)$ & $(0.332)$ & $(0.347)$ & $(0.163)$ & $(0.176)$ \\
\hline \multirow[t]{2}{*}{ Exchange rate volatility } & & 0.763 & & $19.980^{* *}$ & & 1.916 & -3.058 & -3.770 \\
\hline & & $(5.571)$ & & $(7.796)$ & & $(5.201)$ & $(2.856)$ & $(2.647)$ \\
\hline Adjusted $\mathrm{R}^{2}$ & 0.39 & 0.07 & 0.09 & 0.50 & 0.41 & 0.09 & 0.31 & 0.34 \\
\hline No. of obs. & 37 & 41 & 41 & 37 & 37 & 41 & 45 & 45 \\
\hline
\end{tabular}

Notes: The left-hand-side variables, $\log (\mathrm{FDI}), \log (\mathrm{GDP})$ and $\log ($ per capita GDP) are all averaged over 1997-1998. Exchange rate volatility = standard deviation of the first difference in log monthly exchange rate (per US\$) over 1997:1-1998:12. Corruption measure is standardized. 


\section{Table 11: Maturity of Debt}

\begin{tabular}{lcccc}
\hline Dependent variable: portion of short-term bank loan & & \\
\hline Dependent variable & $\begin{array}{c}\text { Short-term bank loan/ } \\
\text { (total loan }\end{array}$ & FDI) & $\begin{array}{c}\text { Short-term bank loan/ } \\
\text { (total loan) }\end{array}$ \\
& GCR/WDR & $\mathrm{TI}$ & GCR/WDR & $\mathrm{TI}$ \\
Corruption & 0.040 & $0.155 \#$ & -0.108 & 0.027 \\
& $(0.082)$ & $(0.102)$ & $(0.083)$ & $(0.089)$ \\
& & & & \\
Log (GDP) & $0.097^{*}$ & 0.067 & -0.013 & -0.009 \\
& $(0.049)$ & $(0.048)$ & $(0.036)$ & $(0.032)$ \\
Log (Per capita GDP) & 0.032 & 0.101 & -0.032 & 0.007 \\
& $(0.063)$ & $(0.080)$ & $(0.058)$ & $(0.060)$ \\
Adjusted R & & & & \\
No. of obs. & 0.04 & 0.09 & 0.03 & 0.003 \\
\hline
\end{tabular}

1. Short-term loans are loans with maturity less than and up to one year.

2. Bank loans for a particular recipient country are its borrowing from all BIS-reporting countries (mostly OECD countries). To maximize comparability, the value of FDI for a host country is the sum of inward FDI from OECD countries (rather than total inward FDI from the balance-of-payments source). 


\section{Table 12: Ability to Borrow Internationally in Own Currency}

\begin{tabular}{|c|c|c|c|c|c|c|c|c|}
\hline \multicolumn{9}{|c|}{ Dependent variable: Ability to Borrow Internationally in Own Currency } \\
\hline Methodology & $\begin{array}{c}\text { OLS } \\
\text { GCR/WDR }\end{array}$ & $\begin{array}{c}\text { OLS } \\
\text { GCR/WDR }\end{array}$ & $\begin{array}{c}\text { Tobit } \\
\text { GCR/WDR }\end{array}$ & $\begin{array}{c}\text { Tobit } \\
\text { GCR/WDR }\end{array}$ & $\begin{array}{l}\text { OLS } \\
\text { TI }\end{array}$ & $\begin{array}{l}\text { OLS } \\
\text { TI }\end{array}$ & $\begin{array}{l}\text { Tobit } \\
\text { TI }\end{array}$ & $\begin{array}{c}\text { Tobit } \\
\text { TI }\end{array}$ \\
\hline Measure of corruption & $\begin{array}{l}-0.252^{\star *} \\
(0.059)\end{array}$ & $\begin{array}{l}-0.115^{* *} \\
(0.052)\end{array}$ & $\begin{array}{l}-0.767^{* *} \\
(0.132)\end{array}$ & $\begin{array}{l}0.008 \\
(0.185)\end{array}$ & $\begin{array}{l}-0.252^{* *} \\
(0.062)\end{array}$ & $\begin{array}{l}-0.074 \\
(0.077)\end{array}$ & $\begin{array}{l}-0.689^{* *} \\
(0.130)\end{array}$ & $\begin{array}{l}-0.067 \\
(0.187)\end{array}$ \\
\hline Log (Per capita GDP) & & $\begin{array}{l}0.109^{* *} \\
(0.031)\end{array}$ & & $\begin{array}{l}0.653^{\star *} \\
(0.167)\end{array}$ & & $\begin{array}{l}0.139^{* *} \\
(0.052)\end{array}$ & & $\begin{array}{l}1.584^{* *} \\
(0.403)\end{array}$ \\
\hline $\begin{array}{l}\text { Adjusted } \mathrm{R}^{2} / \text { Pesudo } \mathrm{R}^{2} \\
\text { No. of obs. }\end{array}$ & $\begin{array}{c}0.28 \\
99 \\
\end{array}$ & $\begin{array}{c}0.34 \\
98 \\
\end{array}$ & $\begin{array}{c}0.30 \\
99 \\
\end{array}$ & $\begin{array}{c}0.46 \\
98 \\
\end{array}$ & $\begin{array}{c}0.24 \\
85 \\
\end{array}$ & $\begin{array}{c}0.29 \\
84 \\
\end{array}$ & $\begin{array}{c}0.24 \\
85 \\
\end{array}$ & $\begin{array}{c}0.37 \\
84 \\
\end{array}$ \\
\hline
\end{tabular}

Notes:

1. Log(per capita GDP) are averaged over 1994-96.

2. Ability to borrow internationally in own currency is measured by proportion of international securities issued in a country's currency relative to the amount issued by that country's residents in 1998. The data were kindly provided by Ernesto Stein and Ugo Panizza. 
Figure 1: Relative Volatility of Different Capital Flows

\section{Standard Devations Over 1980-96 Emerging Marekets: 85 countries}

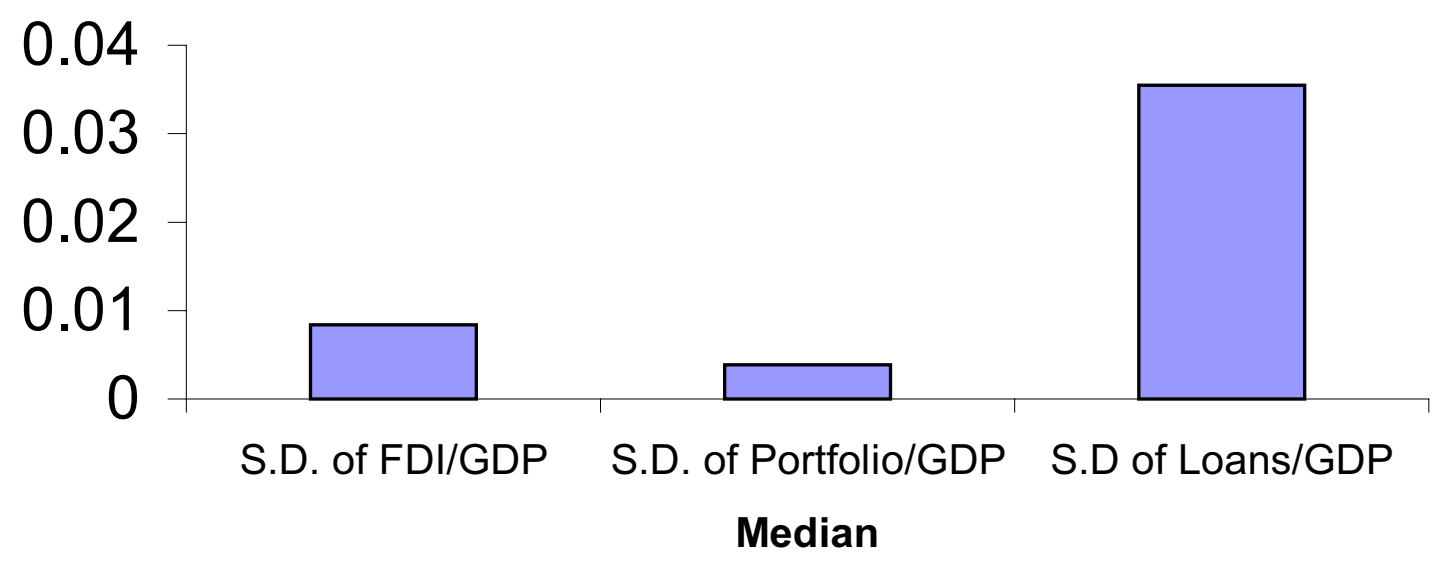

\section{Standard Deviations Over 1980-96}

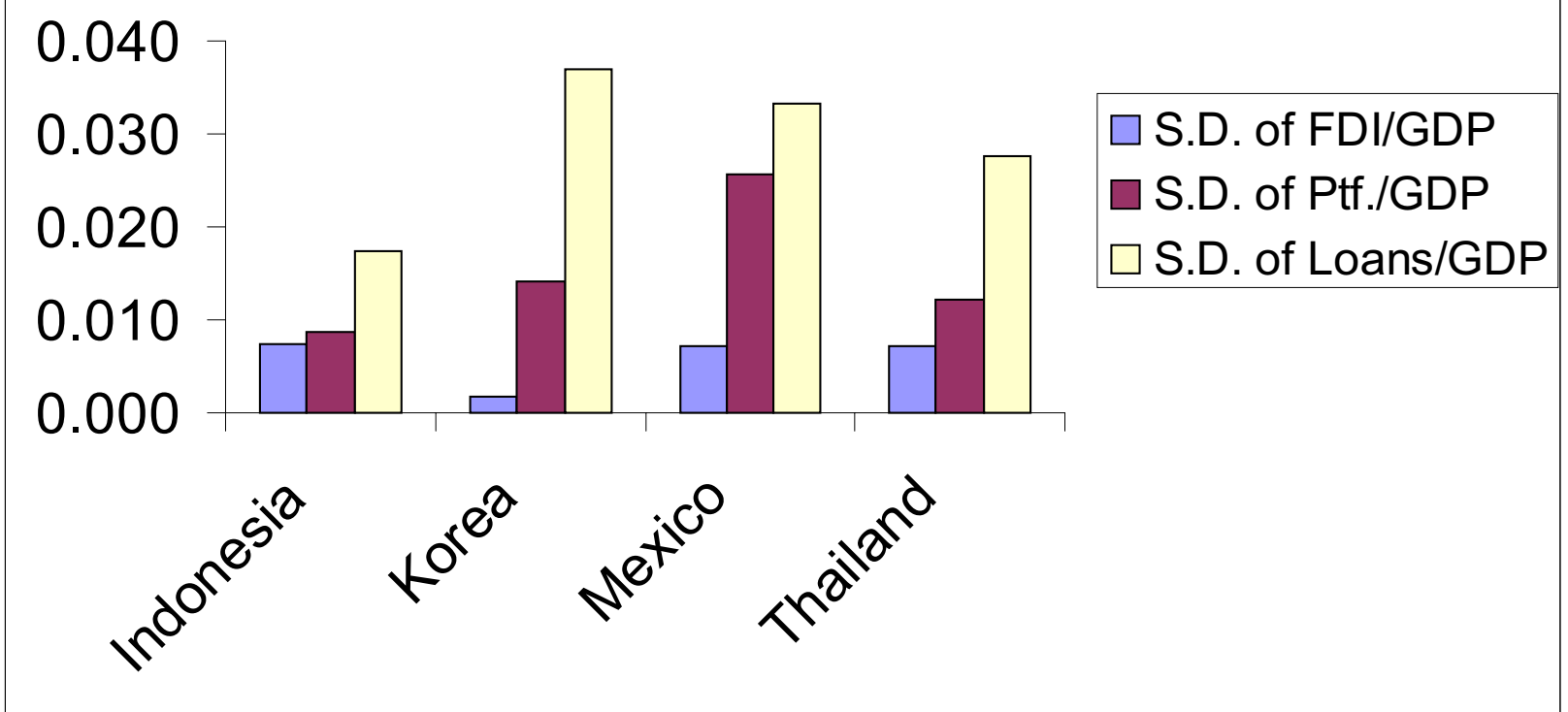


Figure 2:Quality of Public Governance and the Composition of Capital Inflows

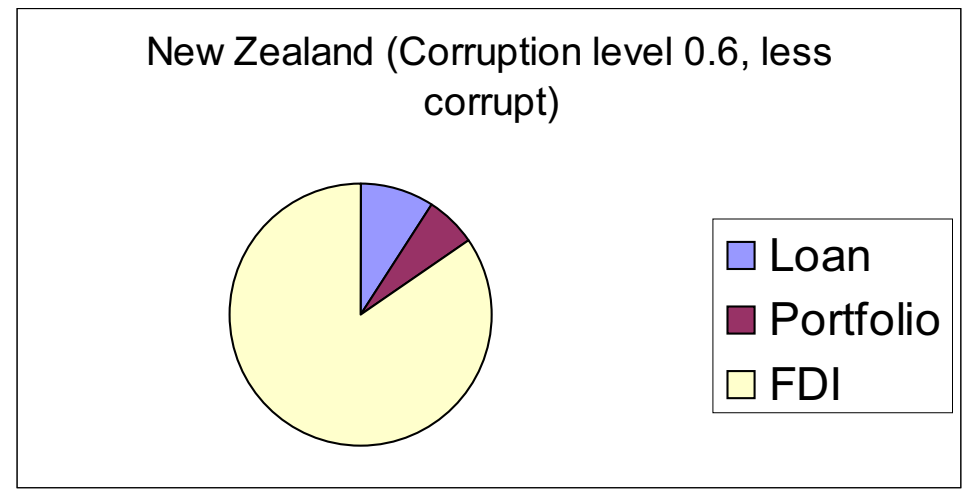

Singapore (Corruption level: 0.9)

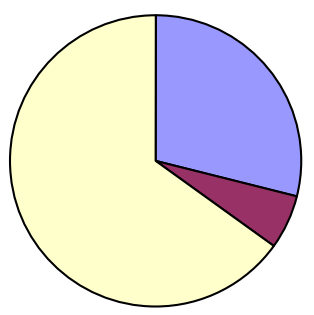

$\square$ Loan

$\square$ Portfolio

$\square$ FDI

Uruguay (Corruption level: 5.7)

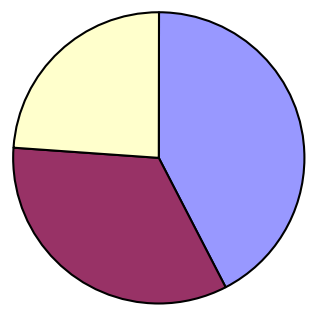

Loan

$\square$ Portfolio

$\square$ FDI

Thailand (Corruption level: 7.0$)$

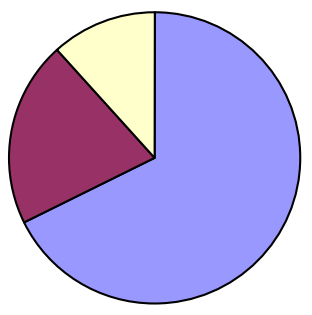

Loan

$\square$ Portfolio

$\square$ FDI 
Figure 3: Composition of Capital Inflows and Corruption (Partial correlation based on Table 7, Column 1)

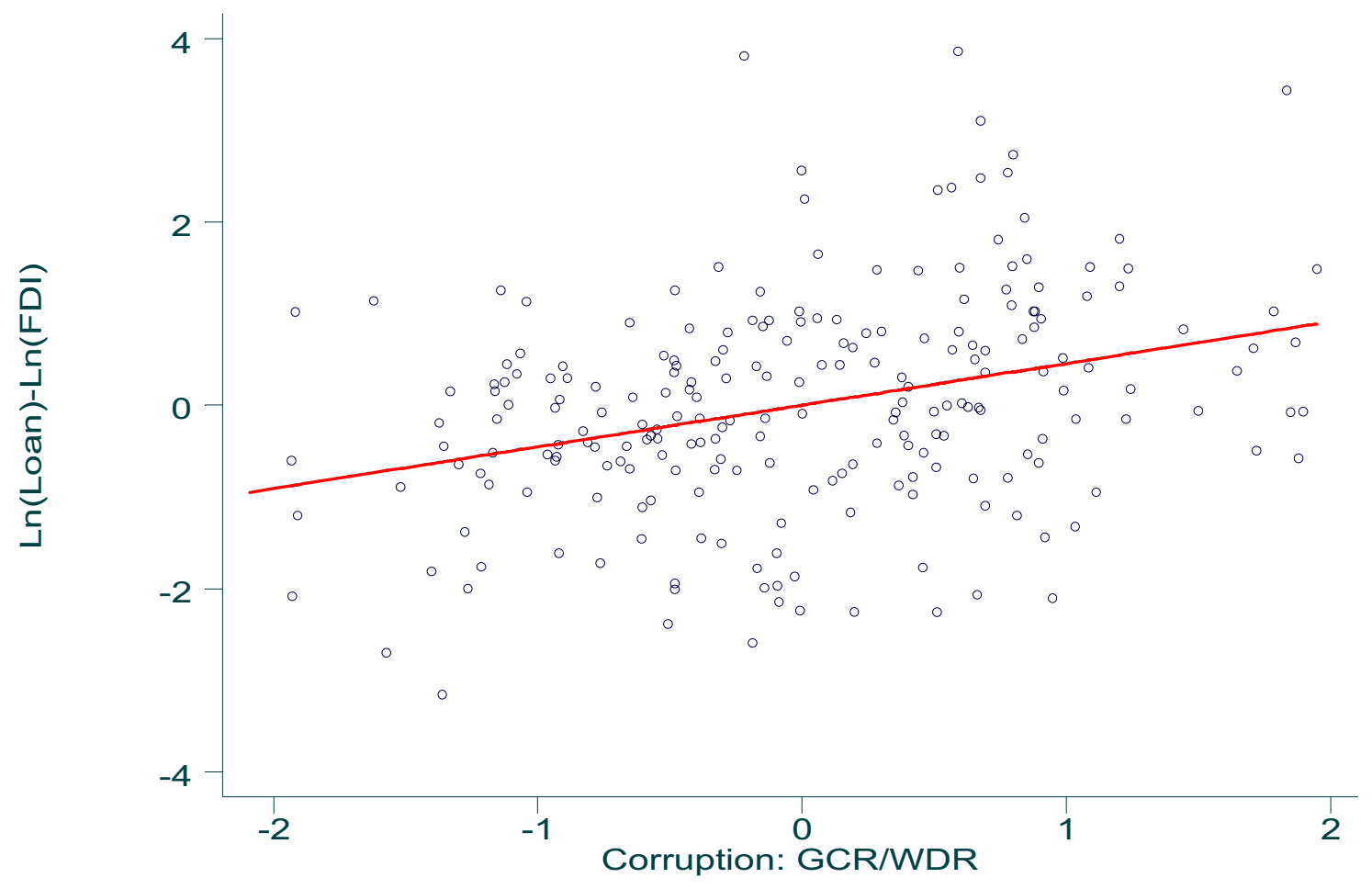




\section{Appendix 1: Justification for the econometric specification that links the composition of capital inflows and corruption}

In the main empirical part of the paper, we have performed several regressions that examine the connection between corruption and the ratio of FDI and non-FDI capital flows is examined. In this section, a simple model is used to demonstrate how such a reduced-form specification can be justified. For simplicity, let us consider that there are two types of international capital flows: direct investment and bank credit.

Let us suppose that the government in the capital-importing country, k, maximizes the following two-period objective function:

$$
\mathrm{U}[\mathrm{G}(\mathrm{k}, 1)]+\delta \mathrm{U}[\mathrm{G}(\mathrm{k}, 2)]
$$

where $\mathrm{G}(\mathrm{k}, 1)$ and $\mathrm{G}(\mathrm{k}, 2)$ are expenditures by the government in Country $\mathrm{k}$ in Period 1 and Period 2, respectively, and $\delta$ is the subjective discount factor. For simplicity, we assume that the tax revenues in the two periods, $\mathrm{T}(\mathrm{k}, 1)$ and $\mathrm{T}(\mathrm{k}, 2)$, are exogenously given. Let $\mathrm{B}(\mathrm{k})$ and $\mathrm{D}(\mathrm{k})$ are first-period borrowing by Country $\mathrm{k}$ from international banks and first-period direct investment in Country k, respectively. To abstract from unnecessary complications, we assume that bank credit and FDI are merely two forms of additional funding sources. No production is explicitly modeled. In this case, the gap between the first-period expenditure and tax revenue has to be met by the inflow of international capital:

$$
\mathrm{G}(\mathrm{k}, 1)=\mathrm{T}(\mathrm{k}, 1)+\mathrm{B}(\mathrm{k})+\mathrm{D}(\mathrm{k})
$$

In the second period, the international credit has to be repaid. Moreover, international direct investors are assumed to recoup both the investment and the gross profit.

$$
\mathrm{G}(\mathrm{k}, 2)=\mathrm{T}(\mathrm{k}, 2)-\mathrm{R}[\mathrm{B}(\mathrm{k})] \mathrm{B}(\mathrm{k})-\mathrm{R}[\mathrm{D}(\mathrm{k})] \mathrm{D}(\mathrm{k})
$$


where $\mathrm{R}[\mathrm{B}(\mathrm{k})]$ and $\mathrm{R}[\mathrm{D}(\mathrm{k})]$ are the gross returns that international creditors and international director investors would demand from Country k. Suppose $\mathrm{R}^{*}$ is the gross return on the risk free bond (say, the US government bond as an approximation), then, we assume that

$$
\mathrm{R}[\mathrm{B}(\mathrm{k})]=\mathrm{R}^{*}+\theta \mathrm{B}(\mathrm{k})
$$

and

$$
\mathrm{R}[\mathrm{D}(\mathrm{k})]=\mathrm{R}^{*}+\theta \mathrm{D}(\mathrm{k})+\rho(\mathrm{k}) \mathrm{D}(\mathrm{k})
$$

Both $\theta$ and $\rho(\mathrm{k})$ are positive. $\rho(\mathrm{k})$ should be thought of proportional to Country k's perceived level of corruption. The positive $\theta$ reflects the assumption that the warranted returns on either bank credit or direct investment increases with the size of the capital inflow. $\rho(\mathrm{k})$ appears in the return on the direct investment but not in that on bank credit because corruption represents a greater risk to direct investment than to bank loans (for the two reasons described in the previous section: Relative to bank lending, FDI face greater sunk costs and less protection from the international financial system).

A few points are worth noting here. First, we assume that the bank credit is obtained and later paid back by the government. Borrowing from international credit market in reality can be done by either private or public sector. Many researchers have observed that the distinction between private and public borrowing is very thin since private borrowing from the international credit market often carries implicit and sometimes explicit guarantee from the government of the borrowing country. Second, while direct investment is supposed to be for the "long term," investors eventually would want to recoup both the initial investment and the cumulative profits along the way.

The government's maximization problem yields the following two first-order conditions:

$$
\mathrm{U}^{\prime}[\mathrm{G}(\mathrm{k}, 1)]-\delta \mathrm{U}^{\prime}[\mathrm{G}(\mathrm{k}, 2)]\left[\mathrm{R}^{*}+2 \theta \mathrm{B}(\mathrm{k})\right]=0
$$

and

$$
\mathrm{U}^{\prime}[\mathrm{G}(\mathrm{k}, 1)]-\delta \mathrm{U}^{\prime}[\mathrm{G}(\mathrm{k}, 2)]\left[\mathrm{R}^{*}+2 \theta \mathrm{B}(\mathrm{k})+2 \rho(\mathrm{k}) \mathrm{D}(\mathrm{k})\right]=0
$$


This implies a particular relationship between the composition of capital inflow for Country k and its corruption level:

$$
\mathrm{B}(\mathrm{k}) / \mathrm{D}(\mathrm{k})=[\theta+\rho(\mathrm{k})] / \theta
$$

Hence, the higher is the corruption level in country k, the less FDI it would receive relative to its bank borrowing. The ratio of non-FDI form of capital flow to FDI can be linked to the recipient country's level of corruption. 


\section{Appendix 2: Source and Construction of the Variables}

\section{Bilateral Bank Loans}

Source: Bank for International Settlements

Data are at the end of December in millions of US\$. Loans to offshore banking centers are omitted.

\section{Bilateral Foreign Direct Investment}

Source: OECD, International Direct Investment Statistics Yearbook 1998, Diskettes. Unit: millions of US\$ (converted into US\$ using the yearly average exchange rates from annex III of the book).

\section{Total Inward FDI, Portfolio and Other Investment}

Source: International Monetary Fund, International Financial Statistics, lines 78bed, 78bgd, and 78bid, respectively.

\section{Distance}

Greater Circle Distance (in kilometers) between economic centers (usually capital cities) in a pair of countries based on the latitude and longitude data.

Source for latitude and longitude: Rudloff, updated from Pearce and Smith. Argentina: used the average latitude and longitude of Buenos Aires, Cordoba, and Rosario Australia: used the average latitude and longitude of Canberra, Sydney, and Melbourne Bahrain: used the latitude and longitude data from the city of Muharraq Bermuda: used the latitude and longitude data from Kindley Air Force Base Bhutan: the latitude and longitude data are from http://www.kingdomofbhutan.com/kingdom.html Canada: used the average latitude and longitude of Toronto, Vancouver, and Montreal Equatorial Guinea: used the latitude and longitude data from the city of Santa Isabel Greenland: used the latitude and longitude data from the city of Peary Land India: used the average latitude and longitude of New Delhi, Bombay, and Calcutta Israel: used the latitude and longitude data from Lod Airport (near Java and Tel Aviv) Mauritius: used the latitude and longitude data from the city of Diego Gracia Netherlands: used the latitude and longitude data from the city of De Bilt Slovak: used the latitude and longitude data from the city of Poprad Sudan: used the average latitude and longitude of Atbara Khartoum and El Fasher Switzerland: used the latitude and longitude data from the city of Zurich Brazil: used the average latitude and longitude of Brasilia, Rio de Janeiro, and Sao Paulo. Panama: used the latitude and longitude data from Panama city Russia: used the average latitude and longitude of Moscow, St. Petersburg and Nizhni Novogorodo. The data for Nzhni Novogorodo is from http://www.unn.runnet.ru/nn/whereis.htm Kazakhstan: used the average latitude and longitude of Almaty, Chimkent, and Karaganda. United States: used the latitude and longitude data from Kansas City, Missouri

\section{Linguistic Tie}

Source of major languages: CIA world facts book, from http://www.odci.gov/cia/publications/factbook/

Dummy $=1$ if the two countries share a common language or have a former colonial relation.

\section{Corruption - GCR Index}

Source: Global Competitiveness Report 1997

Transformation: values in this paper $=8$ - original values. 
Corruption - WDR Index

Original Source: World Development Report 1997.

Data are from Kaufmann and Wei (1999).

Transformation: values in this paper $=8$ - original values.

Corruption -- TI Index

Source: Transparency International (http://www.gwdg.de/ uwvw/icr.htm) 1998 index.

Transformation: Values in this paper $=10$ - minus the original values. Thus, a bigger number means more corruption.

Gross Domestic Product (GDP) and GDP Per Capita

Source: World Bank SIMA/GDF \& WDR central database.

GDP data are GDP at market prices (constant 1995 US\$).

GDP per capita data are calculated using GDP divided by population.

Monthly Exchange Rate (end of period)

Source: IMF, International Financial Statistics, via the World Bank SIMA databases.

Government Deficit to GDP Ratio

Source: World Bank SIMA/GDF \& WDI central database.

US bilateral data:

Source: US Treasury Department website: http://www.ustreas.gov/tic/ticsec.shtml

Sum of the US portfolio investments in other countries(Gross sale by foreigners to US residents, foreign bonds and foreign stocks) from 1994-96.

All amounts in millions of dollars.

Legal origins:

Source: La Porta, Lopez-de-Silanes, Shleifer, and Vishny (1998).

Accounting Standard

Source: La Porta, Lopez-de-Silanes, Shleifer, and Vishny (1998).

Corporate Tax rates:

Source: PwC(2000), updated from GCR (1997). 


\section{Appendix 3: Standard deviation and coefficient of variation of FDI/GDP, loan/GDP and portfolio/GDP by countries}

\begin{tabular}{|c|c|c|c|c|c|c|c|c|c|}
\hline & \multicolumn{3}{|c|}{ FDI/GDP } & \multicolumn{3}{|c|}{$\begin{array}{l}\text { Loan/ } \\
\text { GDP }\end{array}$} & \multicolumn{3}{|c|}{$\begin{array}{l}\text { Portfolio/ } \\
\text { GDP }\end{array}$} \\
\hline & Std. Dev. & Mean & $\begin{array}{l}\text { Coefficient } \\
\text { of variation }\end{array}$ & Std. Dev. & Mean & $\begin{array}{l}\text { Coefficient } \\
\text { of variation }\end{array}$ & Std. Dev. & Mean & $\begin{array}{l}\text { Coefficient } \\
\text { of variation }\end{array}$ \\
\hline Albania & 0.017 & 0.013 & 1.372 & 0.024 & 0.020 & 1.222 & & & \\
\hline Algeria & 0.002 & 0.001 & 3.518 & 0.013 & 0.001 & 16.046 & 0.000 & 0.000 & -3.464 \\
\hline Angola & 0.030 & 0.035 & 0.870 & 0.085 & -0.017 & -4.876 & & & \\
\hline Argentina & 0.006 & 0.010 & 0.614 & 0.032 & 0.020 & 1.623 & 0.034 & 0.021 & 1.618 \\
\hline Australia & 0.009 & 0.018 & 0.469 & 0.016 & 0.016 & 0.971 & 0.015 & 0.028 & 0.513 \\
\hline Austria & 0.004 & 0.005 & 0.830 & 0.019 & 0.011 & 1.672 & 0.012 & 0.027 & 0.426 \\
\hline Bangladesh & 0.000 & 0.000 & 1.319 & 0.009 & 0.025 & 0.346 & 0.001 & 0.000 & 97.667 \\
\hline Benin & 0.020 & 0.013 & 1.551 & 0.060 & 0.013 & 4.570 & 0.000 & 0.000 & -4.650 \\
\hline Bolivia & 0.021 & 0.020 & 1.063 & 0.057 & 0.037 & 1.519 & 0.001 & 0.000 & -2.925 \\
\hline Botswana & 0.036 & 0.024 & 1.494 & 0.023 & 0.023 & 1.002 & 0.001 & 0.000 & 3.396 \\
\hline Brazil & 0.003 & 0.006 & 0.557 & 0.028 & 0.004 & 7.771 & 0.026 & 0.013 & 2.042 \\
\hline Bulgaria & 0.004 & 0.002 & 1.576 & 0.058 & -0.003 & -17.827 & 0.003 & -0.001 & -2.771 \\
\hline Burkina Faso & 0.001 & 0.001 & 1.304 & 0.038 & 0.033 & 1.155 & 0.000 & 0.000 & 3.742 \\
\hline Burundi & 0.001 & 0.001 & 0.726 & 0.036 & 0.053 & 0.675 & & & \\
\hline Cameroon & 0.014 & 0.007 & 1.926 & 0.021 & 0.026 & 0.830 & & & \\
\hline $\begin{array}{l}\text { Canada } \\
\text { Central African }\end{array}$ & 0.006 & 0.011 & 0.573 & 0.005 & 0.004 & 1.234 & 0.014 & 0.035 & 0.400 \\
\hline Rep. & 0.006 & 0.003 & 2.000 & 0.021 & 0.051 & 0.417 & & & \\
\hline Chad & 0.015 & 0.010 & 1.484 & 0.042 & 0.035 & 1.187 & & & \\
\hline Chile & 0.019 & 0.027 & 0.696 & 0.064 & 0.033 & 1.960 & 0.008 & 0.005 & 1.632 \\
\hline China & 0.023 & 0.022 & 1.051 & 0.007 & 0.007 & 1.047 & 0.003 & 0.003 & 1.039 \\
\hline Colombia & 0.008 & 0.015 & 0.550 & 0.020 & 0.019 & 1.039 & 0.008 & 0.005 & 1.702 \\
\hline Congo, Rep. & 0.010 & 0.008 & 1.163 & 0.245 & 0.106 & 2.309 & & & \\
\hline Costa Rica & 0.010 & 0.025 & 0.417 & 0.107 & 0.028 & 3.821 & 0.007 & 0.000 & -203.494 \\
\hline Cote d'Ivoire & 0.009 & 0.006 & 1.507 & 0.060 & 0.052 & 1.145 & 0.001 & 0.000 & 4.386 \\
\hline $\begin{array}{l}\text { Denmark } \\
\text { Dominican }\end{array}$ & 0.009 & 0.008 & 1.172 & 0.036 & 0.016 & 2.202 & 0.035 & 0.020 & 1.753 \\
\hline Republic & 0.008 & 0.014 & 0.576 & 0.036 & 0.023 & 1.580 & 0.013 & 0.004 & 3.742 \\
\hline Ecuador & 0.010 & 0.014 & 0.737 & 0.046 & 0.016 & 2.910 & & & \\
\hline Egypt, Arab Rep. & 0.010 & 0.021 & 0.473 & 0.046 & 0.002 & 29.621 & 0.002 & 0.001 & 3.880 \\
\hline EI Salvador & 0.003 & 0.003 & 0.947 & 0.031 & 0.026 & 1.181 & 0.004 & 0.001 & 3.227 \\
\hline Finland & 0.004 & 0.005 & 0.938 & 0.013 & 0.007 & 1.682 & 0.027 & 0.032 & 0.857 \\
\hline France & 0.005 & 0.009 & 0.545 & 0.022 & 0.023 & 0.921 & 0.015 & 0.014 & 1.066 \\
\hline Gabon & 0.022 & 0.009 & 2.539 & 0.105 & 0.042 & 2.521 & & & \\
\hline Gambia & 0.016 & 0.013 & 1.172 & 0.044 & 0.047 & 0.933 & & & \\
\hline Ghana & 0.011 & 0.007 & 1.510 & 0.022 & 0.043 & 0.515 & & & \\
\hline Greece & 0.002 & 0.011 & 0.139 & 0.015 & 0.032 & 0.485 & & & \\
\hline Guatemala & 0.009 & 0.011 & 0.833 & 0.013 & 0.008 & 1.648 & 0.009 & 0.000 & 40.526 \\
\hline Guinea & 0.004 & 0.005 & 0.743 & 0.038 & 0.062 & 0.610 & & & \\
\hline Haiti & 0.003 & 0.003 & 1.090 & 0.024 & 0.020 & 1.174 & & & \\
\hline Honduras & 0.006 & 0.010 & 0.578 & 0.042 & 0.044 & 0.960 & & & \\
\hline Hungary & 0.031 & 0.021 & 1.465 & 0.035 & 0.025 & 1.374 & 0.032 & 0.013 & 2.494 \\
\hline India & 0.002 & 0.001 & 1.896 & 0.004 & 0.008 & 0.533 & 0.005 & 0.002 & 2.119 \\
\hline Indonesia & 0.007 & 0.009 & 0.820 & 0.017 & 0.024 & 0.717 & 0.009 & 0.005 & 1.722 \\
\hline
\end{tabular}




\begin{tabular}{|c|c|c|c|c|c|c|c|c|c|}
\hline Iran & 0.000 & 0.000 & 3.106 & 0.017 & -0.008 & -2.264 & & & \\
\hline Ireland & 0.011 & 0.014 & 0.778 & 0.033 & 0.008 & 3.885 & 0.031 & 0.025 & 1.282 \\
\hline Italy & 0.002 & 0.003 & 0.617 & 0.008 & 0.010 & 0.814 & 0.022 & 0.016 & 1.348 \\
\hline Jamaica & 0.019 & 0.016 & 1.188 & 0.079 & 0.058 & 1.359 & & & \\
\hline Japan & 0.000 & 0.000 & 1.301 & 0.007 & 0.000 & -48.772 & 0.011 & 0.011 & 0.941 \\
\hline Jordan & 0.008 & 0.006 & 1.355 & 0.038 & 0.049 & 0.771 & & & \\
\hline Kenya & 0.003 & 0.003 & 0.857 & 0.032 & 0.016 & 2.078 & 0.000 & 0.000 & 2.631 \\
\hline Korea, Rep. & 0.002 & 0.003 & 0.591 & 0.037 & 0.018 & 2.039 & 0.014 & 0.011 & 1.338 \\
\hline Lao PDR & 0.026 & 0.018 & 1.493 & 0.028 & 0.053 & 0.528 & 0.000 & 0.000 & 2.441 \\
\hline Lesotho & 0.104 & 0.053 & 1.975 & 0.033 & 0.074 & 0.444 & & & \\
\hline Libya & 0.012 & -0.008 & -1.577 & 0.008 & 0.003 & 2.439 & & & \\
\hline Madagascar & 0.003 & 0.002 & 1.250 & 0.055 & 0.031 & 1.740 & & & \\
\hline Malawi & 0.002 & 0.001 & 2.674 & 0.045 & 0.061 & 0.734 & 0.001 & 0.001 & 1.186 \\
\hline Malaysia & 0.023 & 0.046 & 0.490 & 0.034 & 0.008 & 4.397 & 0.023 & 0.007 & 3.544 \\
\hline Mali & 0.013 & 0.006 & 2.258 & 0.020 & 0.072 & 0.278 & & & \\
\hline Mauritania & 0.010 & 0.009 & 1.082 & 0.089 & 0.126 & 0.703 & 0.000 & 0.000 & -2.197 \\
\hline Mauritius & 0.005 & 0.006 & 0.725 & 0.036 & 0.026 & 1.392 & 0.011 & 0.003 & 3.437 \\
\hline Mean & 0.012 & 0.011 & 1.135 & 0.039 & 0.028 & 0.932 & 0.011 & 0.008 & -0.579 \\
\hline Median & 0.008 & 0.009 & 1.063 & 0.033 & 0.023 & 1.174 & 0.008 & 0.003 & 1.632 \\
\hline Mexico & 0.007 & 0.016 & 0.452 & 0.033 & 0.016 & 2.048 & 0.026 & 0.012 & 2.088 \\
\hline Morocco & 0.006 & 0.007 & 0.753 & 0.036 & 0.029 & 1.245 & 0.002 & 0.001 & 2.606 \\
\hline Mozambique & 0.008 & 0.006 & 1.301 & 0.163 & 0.179 & 0.908 & & & \\
\hline Nepal & 0.001 & 0.000 & 4.123 & 0.015 & 0.039 & 0.374 & & & \\
\hline Netherlands & 0.011 & 0.021 & 0.490 & 0.012 & 0.008 & 1.428 & 0.014 & 0.018 & 0.809 \\
\hline New Zealand & 0.018 & 0.037 & 0.477 & 0.036 & 0.012 & 2.937 & 0.011 & 0.003 & 3.189 \\
\hline Nicaragua & 0.016 & 0.008 & 1.878 & 0.195 & 0.070 & 2.794 & 0.002 & 0.001 & 3.241 \\
\hline Niger & 0.011 & 0.004 & 2.672 & 0.034 & 0.034 & 0.979 & & & \\
\hline Nigeria & 0.026 & 0.028 & 0.936 & 0.061 & -0.066 & -0.931 & 0.020 & 0.009 & 2.211 \\
\hline Norway & 0.009 & 0.007 & 1.298 & 0.011 & 0.006 & 1.686 & 0.023 & 0.011 & 2.061 \\
\hline Oman & 0.006 & 0.013 & 0.459 & 0.029 & 0.016 & 1.815 & & & \\
\hline Pakistan & 0.004 & 0.006 & 0.638 & 0.011 & 0.027 & 0.409 & 0.007 & 0.004 & 1.779 \\
\hline $\begin{array}{l}\text { Panama } \\
\text { Papua New }\end{array}$ & 0.050 & 0.018 & 2.833 & 0.187 & 0.017 & 10.755 & 0.094 & 0.022 & 4.273 \\
\hline Guinea & 0.019 & 0.037 & 0.506 & 0.077 & 0.008 & 9.981 & 0.102 & 0.069 & 1.480 \\
\hline Paraguay & 0.008 & 0.009 & 0.920 & 0.025 & 0.012 & 2.023 & 0.001 & 0.000 & 30.180 \\
\hline Peru & 0.020 & 0.011 & 1.843 & 0.060 & 0.018 & 3.308 & 0.004 & 0.002 & 1.648 \\
\hline Philippines & 0.009 & 0.010 & 0.921 & 0.026 & 0.027 & 0.956 & 0.017 & 0.008 & 1.979 \\
\hline Poland & 0.011 & 0.007 & 1.625 & 0.060 & 0.012 & 5.186 & 0.002 & 0.001 & 4.062 \\
\hline Portugal & 0.010 & 0.015 & 0.688 & 0.034 & 0.014 & 2.407 & 0.019 & 0.016 & 1.199 \\
\hline Romania & 0.005 & 0.004 & 1.234 & 0.051 & 0.003 & 19.273 & 0.012 & 0.004 & 3.023 \\
\hline Rwanda & 0.005 & 0.007 & 0.719 & 0.015 & 0.025 & 0.627 & 0.000 & 0.000 & 2.677 \\
\hline Saudi Arabia & 0.029 & 0.012 & 2.398 & & & & & & \\
\hline Senegal & 0.008 & 0.004 & 2.026 & 0.043 & 0.073 & 0.583 & 0.001 & 0.000 & 1.520 \\
\hline Sierra Leone & 0.044 & -0.007 & -6.311 & 0.041 & 0.031 & 1.330 & 0.000 & 0.000 & -4.000 \\
\hline Somalia & 0.007 & -0.003 & -2.045 & 0.077 & 0.116 & 0.667 & & & \\
\hline South Africa & 0.004 & 0.001 & 3.185 & 0.015 & 0.003 & 5.954 & 0.013 & 0.006 & 2.272 \\
\hline Spain & 0.006 & 0.016 & 0.397 & 0.012 & 0.007 & 1.632 & 0.032 & 0.015 & 2.133 \\
\hline Sri Lanka & 0.004 & 0.008 & 0.515 & 0.019 & 0.085 & 0.227 & 0.006 & -0.003 & -2.190 \\
\hline Sudan & 0.000 & 0.000 & 3.858 & 0.020 & 0.025 & 0.811 & & & \\
\hline Sweden & 0.016 & 0.013 & 1.261 & 0.023 & 0.039 & 0.598 & 0.029 & 0.000 & 132.630 \\
\hline
\end{tabular}




\begin{tabular}{lccccccccc}
\hline Switzerland & 0.006 & 0.011 & 0.483 & 0.007 & 0.004 & 1.835 & 0.021 & 0.024 & 0.889 \\
Syrian Arab & & & & & & & & & \\
Republic & 0.005 & 0.002 & 2.139 & 0.046 & 0.036 & 1.277 & & & \\
Thailand & 0.007 & 0.013 & 0.571 & 0.028 & 0.044 & 0.629 & 0.012 & 0.011 & 1.137 \\
Togo & 0.012 & 0.008 & 1.417 & 0.048 & 0.026 & 1.857 & 0.001 & 0.001 & 1.056 \\
Trinidad and & & & & & & & & & \\
Tobago & 0.029 & 0.033 & 0.865 & 0.026 & 0.002 & 12.877 & 0.001 & 0.000 & 6.616 \\
Tunisia & 0.012 & 0.019 & 0.644 & 0.017 & 0.024 & 0.710 & 0.003 & 0.004 & 0.895 \\
Turkey & 0.002 & 0.003 & 0.637 & 0.025 & 0.005 & 4.623 & 0.008 & 0.007 & 1.056 \\
Uganda & 0.009 & 0.005 & 1.830 & 0.035 & 0.033 & 1.080 & & & \\
United Kingdom & 0.009 & 0.017 & 0.518 & 0.063 & 0.047 & 1.343 & 0.028 & 0.032 & 0.875 \\
United States & 0.003 & 0.008 & 0.425 & 0.000 & 0.000 & -2.828 & 0.012 & 0.015 & 0.769 \\
Uruguay & 0.007 & 0.005 & 1.420 & 0.033 & 0.017 & 1.984 & 0.012 & 0.013 & 0.914 \\
Venezuela & 0.011 & 0.008 & 1.335 & 0.080 & -0.017 & -4.814 & 0.089 & 0.026 & 3.417 \\
Zambia & 0.019 & 0.020 & 0.926 & 0.089 & 0.075 & 1.186 & & & \\
Zimbabwe & 0.002 & 0.000 & 8.913 & 0.036 & 0.035 & 1.035 & 0.004 & -0.004 & -0.853 \\
\hline
\end{tabular}

Empty cells indicate missing data or zero mean. 


\section{Appendix 4: Corruption and Bank Lending}

\begin{tabular}{|c|c|c|c|c|c|}
\hline Lending country & all & all & France & Japan & USA \\
\hline Methodology & Fixed Effects & Fixed Effects & OLS & OLS & OLS \\
\hline Measure of corruption & GCR/WDR & GCR/WDR & GCR/WDR & GCR/WDR & GCR/WDR \\
\hline \multirow[t]{2}{*}{ Corruption } & $0.376^{\star \star}$ & $0.286^{\star *}$ & $0.419^{*}$ & 0.427 & $0.747^{* *}$ \\
\hline & $(0.092)$ & $(0.107)$ & $(0.221)$ & $(0.363)$ & $(0.344)$ \\
\hline \multirow{2}{*}{$\begin{array}{l}\text { Ease in investing in } \\
\text { securities and bonds market }\end{array}$} & $0.219^{* *}$ & $0.257^{*}$ & 0.253 & 0.402 & $0.591^{*}$ \\
\hline & $(0.088)$ & $(0.134)$ & $(0.211)$ & $(0.433)$ & $(0.311)$ \\
\hline \multirow[t]{2}{*}{ Tax rate } & & -0.009 & & & \\
\hline & & $(0.015)$ & & & \\
\hline \multirow[t]{2}{*}{ FDI incentives } & & -0.081 & & & \\
\hline & & $(0.121)$ & & & \\
\hline \multirow[t]{2}{*}{ FDI restrictions } & & -0.001 & & & \\
\hline & & $(0.078)$ & & & \\
\hline \multirow[t]{2}{*}{$\log (\mathrm{GDP})$} & $1.004^{* *}$ & $1.065^{\star *}$ & $0.860^{\star *}$ & $1.081^{* *}$ & $1.229^{\star *}$ \\
\hline & $(0.054)$ & $(0.109)$ & $(0.131)$ & $(0.222)$ & $(0.187)$ \\
\hline \multirow[t]{2}{*}{ Log (Per capita GDP) } & $0.366^{\star *}$ & $0.281^{* *}$ & 0.078 & $0.492^{*}$ & $0.340 \#$ \\
\hline & $(0.063)$ & $(0.088)$ & $(0.156)$ & $(0.273)$ & $(0.220)$ \\
\hline \multirow[t]{2}{*}{ Log distance } & $-0.244^{\star *}$ & $-0.235^{\star *}$ & 0.245 & $-1.451^{* *}$ & $-1.392^{\star *}$ \\
\hline & $(0.072)$ & $(0.080)$ & $(0.179)$ & $(0.655)$ & $(0.624)$ \\
\hline \multirow[t]{2}{*}{ Linguistic tie } & $0.633^{* *}$ & $0.542^{* *}$ & -0.528 & -1.585 & 0.689 \\
\hline & $(0.207)$ & $(0.236)$ & $(0.914)$ & $(1.872)$ & $(0.607)$ \\
\hline \multirow[t]{2}{*}{ Exchange rate volatility } & $-5.917^{* *}$ & $-5.781^{* *}$ & $-9.459^{* *}$ & -1.298 & $-15.111^{\star *}$ \\
\hline & $(1.564)$ & $(1.781)$ & $(3.473)$ & $(8.374)$ & $(5.250)$ \\
\hline \multirow{2}{*}{$\begin{array}{l}\text { Adjust } \mathrm{R}^{2} \\
\text { No. of observations. }\end{array}$} & 0.72 & 0.69 & 0.75 & 0.57 & 0.65 \\
\hline & 396 & 317 & 32 & 30 & 30 \\
\hline
\end{tabular}

Note: Source country fixed effects are included in the first two regressions. Standard errors are in parentheses. ** and * indicate significant at the five and ten percent levels, respectively. 